\title{
OSTEOINDUCTIVE BIOMATERIALS: CURRENT KNOWLEDGE OF PROPERTIES, EXPERIMENTAL MODELS AND BIOLOGICAL MECHANISMS
}

\author{
Ana M.C. Barradas ${ }^{1}$, Huipin Yuan ${ }^{1,2}$, Clemens A. van Blitterswijk ${ }^{1}$ and Pamela Habibovic ${ }^{1, *}$ \\ ${ }^{1}$ Department of Tissue Regeneration, University of Twente, MIRA Institute for Biomedical Technology and \\ Technical Medicine, Enschede, The Netherlands \\ ${ }^{2}$ Progentix Orthobiology BV, Bilthoven, The Netherlands
}

\begin{abstract}
In the past thirty years, a number of biomaterials have shown the ability to induce bone formation when implanted at heterotopic sites, an ability known as osteoinduction. Such biomaterials - osteoinductive biomaterials - hold great potential for the development of new therapies in bone regeneration. Although a variety of well characterised osteoinductive biomaterials have so far been reported in the literature, scientists still lack fundamental understanding of the biological mechanism underlying the phenomenon by which they induce bone formation. This is further complicated by the observations that larger animal models are required for research, since limited, if any, bone induction by biomaterials is observed in smaller animals, including particularly rodents. Besides interspecies variation, variations among individuals of the same species have been observed. Furthermore, comparing different studies and drawing general conclusions is challenging, as these usually differ not only in the physico-chemical and structural properties of the biomaterials, but also in animal model, implantation site and duration of the study. Despite these limitations, the knowledge of material properties relevant for osteoinduction to occur has tremendously increased in the past decades. Here we review the properties of osteoinductive biomaterials, in the light of the model and the conditions under which they were tested. Furthermore, we give an insight into the biological processes governing osteoinduction by biomaterials and our view on the future perspectives in this research field.
\end{abstract}

Keywords: Osteoinduction, biomaterials, ceramics, calcium phosphates, bone regeneration.

*Address for correspondence:

Pamela Habibovic

Department of Tissue Regeneration

University of Twente

MIRA Institute for Biomedical Technology and Technical

Medicine

Zuidhorst ZH147, Drienerlolaan 5,

7522 NB Enschede, The Netherlands

Telephone Number: +31 612186343

E-mail: p.habibovic@tnw.utwente.nl

\section{Definitions and Historical Background}

One of the first definitions of osteoinduction, as proposed by Friedenstein, was "the induction of undifferentiated inducible osteoprogenitor cells that are not yet committed to the osteogenic lineage to form osteoprogenitor cells" (Friedenstein, 1968). Although the phenomenon of bone formation upon implantation of various tissues heterotopically was described as early as in the beginning of the $20^{\text {th }}$ century (Huggins, 1931; Levander, 1934; Bertelsen, 1944; Urist and McLean, 1952; Moss, 1958), Urist's seminal discovery that acellular, devitalised, decalcified bone matrix induced bone formation in muscles of mouse, rat, guinea pig and rabbit (Urist, 1965), and subsequent identification of Bone Morphogenetic Proteins (BMPs) as sole inducers of heterotopic bone formation (Urist et al., 1967; Urist and Strates, 1971), set a landmark in this field of research. Based on his studies, Urist defined the process of bone formation by autoinduction, or osteoinduction as "the mechanism of cellular differentiation towards bone of one tissue due to the physicochemical effect or contact with another tissue" (Urist et al., 1967). More recently, in a definition proposed by Wilson-Hench, osteoinduction was described as the process by which osteogenesis is induced (Wilson-Hench, 1987). It is now generally accepted that a conclusive evidence for osteoinduction can only be given by heterotopic implantation, i.e. implantation in the tissues or organs where bone does not naturally grow.

Heterotopic bone induction as induced by Demineralised Bone Matrix (DBM) and BMPs has been well described by Urist and others. When BMPs, loaded onto insoluble collagenous bone matrix, or DBM are implanted heterotopically in rodents, a cascade of events is initiated: the chemotaxis of undifferentiated mesenchymal cells followed by cell proliferation; differentiation into chondroblasts and chondrocytes, followed by the formation of cartilaginous extracellular matrix containing type II collagen and proteoglycans; chondrocytes maturation, hypertrophy, and cartilage calcification; blood vessels and osteoprogenitor infiltration, removal of cartilage and osteoid apposition and bone matrix production; bone marrow formation and bone remodelling (Reddi, 1981). Although it is generally thought that heterotopic induction of bone formation by BMPs is indeed endochondral (Reddi, 1981), there have been reports on intramembranous induction, i.e. direct bone formation without cartilage intermediate, at heterotopic sites. For example, fibrous collagen membrane (Sasano et al., 1993), hydroxyapatite (HA) (Kuboki et al., 1995) and biomimetic calcium phosphate coatings (Liu et al., 2005 ) in combination with BMP induced bone formation 
directly, without apparent cartilage intermediate. In contrast, BMP on fibrous glass membrane and insoluble bone matrix showed that heterotopic bone was formed following the process of endochondral ossification (Sasano et al., 1993; Kuboki et al., 1995;). Differences in the pathway by which heterotopic bone is induced by BMPs may be associated with differences in vascularisation, and hence oxygen supply as well as with mechanical properties (e.g., micromotion) of the carrier (Kuboki et al., 1995).

At the time of Urist's discovery of BMPs as osteoinductive factors, the phenomenon of osteoinduction triggered by a completely synthetic biomaterial, by no means resembling the composition of implants used in Urist's studies, was also reported. In 1960, Selye and coworkers implanted Pyrex ${ }^{\circledR}$ glass tubes, with a diameter of $30 \mathrm{~mm}$ and a length of $20 \mathrm{~mm}$, the so-called tissue diaphragms, subcutaneously in rats. Histological analysis of tissue formed inside the diaphragms 60 days following implantation, revealed the presence of bone, cartilage and hemopoietic tissue (Selye et al., 1960). In 1968, Winter and Simpson described subcutaneous bone formation upon implantation of poly-hydroxyethylmethacrylate (polyHEMA) in pigs (Winter and Simpson, 1969). The authors observed that the implanted sponge had calcified prior to bone formation. Calcification of the sponge was also observed after subcutaneous implantation in rats (Winter, 1970). The observed phenomenon of bone induction by the polymeric sponge could not be explained by the Urist's theory, as the sponge neither contained nor produced BMPs. Interestingly, in earlier reports it was observed that bone was induced by tendons and arteries only if they were first calcified in vivo, as reviewed by De Groot (De Groot, 1973). Although the exact underlying phenomenon was not known, these observations suggested that calcification, and hence calcium phosphates might play an important role in the process of osteoinduction.

In the past decade, a large number of publications illustrated osteoinduction by diverse calcium phosphate biomaterials in the form of sintered ceramics (Yamasaki, 1990; Ripamonti, 1991; Zhang, 1991; Vargervik, 1992; Yamasaki and Sakai, 1992; Klein et al., 1994; Pollick et al., 1995; Ripamonti, 1996), cements (Yuan et al., 2000; Gosain et al., 2002; Habibovic et al., 2008a), coatings (Barrere et al., 2003; Habibovic et al., 2004), as well as coral-derived ceramics (Ripamonti, 1991; Pollick et al., 1995; Magan and Ripamonti, 1996; Ripamonti, 1996; Ripamonti et al., 2009; Ripamonti et al., 2010), in various animal models. Also composites consisting of a polymer and HA have shown to be able to induce bone formation heterotopically (Hasegawa et al., 2007; Barbieri et al., 2010). Besides calcium phosphate containing biomaterials, osteoinduction was also observed in alumina ceramic (Yuan et al., 2001c), titanium (Fujibayashi et al., 2004; Takemoto et al., 2005) and a porous bioglass (Yuan et al., 2001b).

Until now, the exact mechanism of osteoinduction by biomaterials is still incompletely understood. It is furthermore questionable whether the mechanisms of osteoinduction by BMPs and osteoinduction by inorganic biomaterials are related and, if so, to which extent. The apparent differences between osteoinduction by BMPs and biomaterials are that (1) bone induced by biomaterials is always intramembranous (Ripamonti, 1991; Yuan et al., 2002) while BMP-induced bone is mostly formed via the endochondral pathway (Reddi, 1981), (2) in small animals like rodents bone is very rarely induced by synthetic biomaterials (Ohgushi et al., 1989; Ohgushi et al., 1993; Klein et al., 1994; Yang et al., 1996; Yuan et al., 2006b), but easily by BMPs (Reddi, 1992; Reddi, 1994; Wozney, 1998), (3) bone induction by biomaterials in large animals is rather slow, requiring weeks to months (Gosain et al., 2002; Fujibayashi et al., 2004; Habibovic et al., 2005; Habibovic et al., 2006c; Ripamonti et al., 2010), whereas osteoinduction by BMP-2 and BMP-7 takes place as early as 2-3 weeks upon heterotopic implantation in rodents (Ono et al., 1995; Liu et al., 2005; Kato et al., 2006) and (4) while bone is usually observed inside pores or other "protective" areas of a material (Ripamonti et al., 1999; Habibovic et al., 2005; Le Nihouannen et al., 2005; Habibovic et al., 2008 b), bone formation by BMPs is regularly seen on the periphery of the carrier and even in the soft tissue distant from the carrier surface (Yuan et al., 2001d; Liu et al., 2005).

The osteoinductive capacity was one of the main reasons for development of clinical therapies based on BMPs, and both BMP-2 and BMP-7 are currently successfully used in a number of applications (Vaccaro et al., 2004; Boakye et al., 2005). It is therefore not surprising that biomaterials with intrinsic osteoinductivity possess a great potential as alternatives to biological approaches to bone regeneration (Yuan et al., 2010).

As mentioned earlier, it is well established that, to be considered osteoinductive, a material should induce bone formation heterotopically, so that de novo bone origin is solely attributed to its osteoinductive properties rather than to the osteoconductive ones (the latter comprises the migration of potentially osteogenic cells to the site of future matrix formation at the site of (orthotopic) implantation (Davies and Hosseini, 2000). Studies within the field generally describe the chemical and physical properties of osteoinductive materials, as well as the animal model chosen for experimentation. Analysis is usually based on qualitative and quantitative assessment of bone formation induced by different materials and/or at different time points by which critical properties of the setup can be indentified and results explained. Some of the publications also discuss possible biological mechanisms behind the findings, but the driver for bone formation has not been conclusively proven yet.

In the first part of this review, we will discuss the status of osteoinduction by (mostly synthetic) biomaterials, by denoting those that have been identified as osteoinductive with special emphasis on calcium phosphate based ones, as these are the most extensively investigated. We will discuss the properties of the materials, which are, in our view, essential for osteoinduction to occur. The experimental conditions in which materials were tested and their implications for the outcome as well as the availability of in vitro models to predict osteoinductivity will also be elaborated on. Finally, we will focus on the existing theories regarding the mechanism of osteoinduction by biomaterials and provide our view on the topic. 


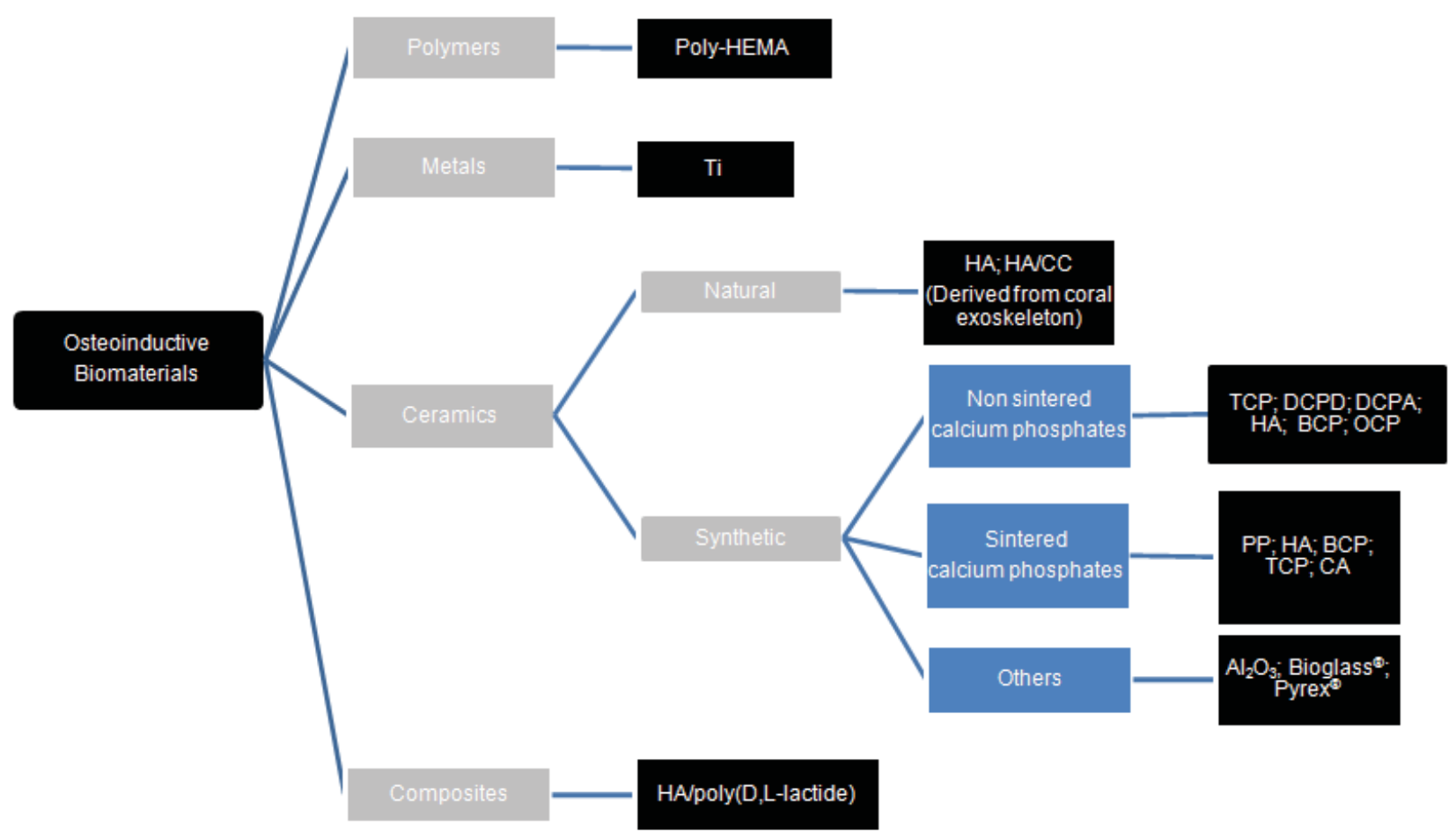

Fig. 1. Schematic diagram presenting materials that have been described as osteoinductive, divided according to material family, origin and physico-chemical and structural properties. Poly-HEMA: poly-hydroxyethylmethacrylate; Ti: titanium; PP: pyrophosphate; HA: hydroxyapatite; CC: calcium carbonate; BCP: biphasic calcium phosphate; TCP: tricalcium phosphate; DCPD: dicalcium phosphate dihydrate; DCPA: dicalcium phosphate anhydrous; CA: carbonated apatite; OCP: octacalcium phosphate.

\section{Osteinductive Biomaterials}

As can be seen in Fig. 1, which is a schematic representation of the biomaterials that have so far been shown to be osteoinductive, all material types, polymers, metals and both synthetic ceramics and ceramics of natural origin, theoretically possess the osteoinductive potential. Glass cylinders (Selye et al., 1960) and poly-HEMA (Winter and Simpson, 1969) were the first synthetic materials associated with heterotopic bone formation and so far, poly-HEMA remains the only osteoinductive polymer. Composites, consisting of polylactide and HA particles have however recently shown to be osteoinductive too (Hasegawa et al., 2007; Barbieri et al., 2010). In the family of metals, porous titanium (Ti) has shown osteoinductivity, alone (Fujibayashi et al., 2004; Takemoto et al., 2005), coated with a thin layer of calcium phosphate (Barrere et al., 2003) or in a construct with a calcium phosphate ceramic (Li et al., 2007).

In contrast to the limited number of reports on osteoinduction by polymers and metals, ceramics particularly calcium phosphate based ones - have shown osteoinductive potential in a variety of studies: HA (Ripamonti, 1991; Vargervik, 1992; Yamasaki and Sakai, 1992; van Eeden and Ripamonti, 1994; Pollick et al., 1995; Magan and Ripamonti, 1996; Ripamonti, 1996; Yuan et al., 1999; Ripamonti et al., 2009), $\beta$-tricalcium phosphate ( $\beta$-TCP) (Yuan et al., 2001a; Yuan et al., 2001e), biphasic calcium phosphate (BCP), that designates the mixture of HA and TCP (Yang et al., 1996; Gosain et al., 2002), dicalcium phosphate anhydrous (DCPA), dicalcium phosphate dihydrate (DCPD) (Habibovic et al., 2008a), carbonated apatite (Habibovic et al., 2008b), calcium pyrophosphates (CPP) (Vargervik, 1992; Toth et al., 1993) and HA/calcium carbonate (CC) mixtures (Pollick et al., 1995; Ripamonti et al., 2010). A case of osteoinductive glass ceramic has also been reported (Yuan et al., 2001b).

A thorough analysis of the materials described so far as osteoinductive (Table 1), could in theory provide answers about properties relevant to osteoinduction. And yet, we are still unable to describe how exactly an osteoinductive material should be designed and produced. The main reason is that the properties of the end material greatly depend on the processing parameters, which often differ among research groups. For example, two porous HA ceramics, prepared by two different groups, may be equal with regard to chemical composition (both can be phase-pure), but completely different in their macroporosity, grain size and surface roughness, and hence differ in their osteoinductive potential. This phenomenon is not unique to osteoinductivity. The capacity to repair bone defects can differ greatly among materials from the same family, and surgeons can now choose from 13 different calcium phosphate based ceramics/cements in the Netherlands alone for applications in trauma- and orthopaedic-surgery (Van der Stok et al., 2011). Both the starting materials and processing parameters affect properties of the end product, and hence its bioactivity, 
Table 1. (in 5 parts) Overview of the publications referring to osteoinductive materials, divided into material families (polymers, metals, ceramics and composites/hybrids) and sub-categories in the case of ceramic materials (natural and synthetic calcium phosphate ceramics and cements, calcium phosphate coatings and other ceramics, including glass (ceramic) and alumina ceramic). In addition, information is provided about animal model and implantation site, implantation time and material physico-chemical characteristics (chemical composition, form/shape, porous structure) and whether bone formation was observed, according to the original descriptions. IM: intramuscular implantation; SC: subcutaneous implantation; CaPP: calcium pyrophosphate; HA: hydroxyapatite; BCP: biphasic calcium phosphate; TCP: tricalcium phosphate; $\mathrm{xHA} / \mathrm{yTCP}: \mathrm{x}$ and $\mathrm{y}$ are the fraction (in \%) of HA and TCP phases respectively in BCP; CaP: calcium phosphate; CC: calcium carbonate; DCPD: dicalcium phosphate dihydrate; DCPA: dicalcium phosphate anhydrous; PLA: polylactic acid; PDLLAL poly(D,L) lactide; CA: carbonate apatite; OCP: octacalcium phosphate; Ti: titanium; Ta: tantalum; I/II/...: each number represents a different manufacturer or different origin of the powder; STx $(\mathrm{x}=1,2,3, \ldots)$ : each value of $\mathrm{x}$ represents a different ST (sintering temperature); CMT: cement (otherwise it is a sintered ceramic); PH: pre-hardened; *: refers to the surface of the disc; +/-: whether a certain material induced/did not induce bone formation in that particular study at, at least one of the investigated time points (bone incidence among individuals or bone amounts are not compared); NM: not mentioned in the original article; shape can be a cylinder, disc, rod, block and cube, when implanted in the form of solid pieces of material (in the case of calcium phosphate ceramics).

\begin{tabular}{|c|c|c|c|c|c|c|}
\hline \multirow[b]{2}{*}{$\begin{array}{l}\text { Authorship, } \\
\text { Publication } \\
\quad \text { Year }\end{array}$} & \multirow[b]{2}{*}{$\begin{array}{l}\text { Animal } \\
\text { model }\end{array}$} & \multirow[b]{2}{*}{$\begin{array}{l}\text { Implantation } \\
\text { time (days) }\end{array}$} & \multicolumn{4}{|c|}{ Materials } \\
\hline & & & $\begin{array}{c}\text { Chemical } \\
\text { Composition/ } \\
\text { Commercial name }\end{array}$ & Form/Shape & Porous/Dense & Bone \\
\hline \multicolumn{7}{|c|}{ CERAMICS } \\
\hline \multicolumn{7}{|c|}{ Calcium Phosphate Ceramics } \\
\hline $\begin{array}{c}\text { (Ripamonti, } \\
\text { 1991) }\end{array}$ & $\begin{array}{l}\text { Baboon; } \\
\text { IM }\end{array}$ & $30 / 60 / 120$ & HA & Cylinder & Porous & + \\
\hline $\begin{array}{c}\text { (Vargervik, } \\
\text { 1992) }\end{array}$ & $\begin{array}{l}\text { Monkey; } \\
\text { SC; IM }\end{array}$ & $28 / 98$ & HA & Block & Porous & + \\
\hline $\begin{array}{l}\text { (Yamasaki } \\
\text { and Sakai, } \\
\text { 1992) }\end{array}$ & Dog; SC & $30 / 90 / 180$ & HA & Granules & $\begin{array}{l}\text { Dense } \\
\text { Porous }\end{array}$ & $\begin{array}{l}- \\
+\end{array}$ \\
\hline $\begin{array}{c}\text { (Toth et al., } \\
\text { 1993) }\end{array}$ & Dog; SC & 180 & $\begin{array}{c}60 \mathrm{HA} / 40 \beta \mathrm{TCP} \\
\alpha \mathrm{CaPP} \\
\beta \mathrm{CaPP}\end{array}$ & Granules & Porous & $\begin{array}{l}+ \\
+ \\
+\end{array}$ \\
\hline \multirow{2}{*}{$\begin{array}{c}\text { (Klein et al., } \\
\text { 1994) }\end{array}$} & Dog; IM & $\begin{array}{c}30 / 90 / \\
150 / 210\end{array}$ & $\begin{array}{c}\text { HA (I) } \\
\text { HA (I) } \\
\text { HA (II) } \\
\text { HA/ } \alpha \mathrm{TCP}(\mathrm{I}) \\
\text { HA/ } \alpha \mathrm{TCP}(\mathrm{I})\end{array}$ & Cylinder & Dense & $\begin{array}{l}- \\
+ \\
+ \\
+ \\
+\end{array}$ \\
\hline & Rat; SC & $21 / 42 / 84$ & $\begin{array}{c}\text { HA (II) } \\
70 \mathrm{HA} / 30 \beta T C P \text { (II) } \\
30 \mathrm{HA} / 70 \beta \mathrm{TCP} \text { (II) } \\
\beta \mathrm{TCP} \text { (II) } \\
\end{array}$ & $\mathrm{NM}$ & Porous & $\begin{array}{l}- \\
- \\
- \\
-\end{array}$ \\
\hline $\begin{array}{c}\text { (Pollick et al., } \\
\text { 1995b) }\end{array}$ & $\begin{array}{c}\text { Dog; } \\
\text { IM, SC }\end{array}$ & 120 & $\begin{array}{c}\mathrm{HA} \\
\mathrm{HA} / \mathrm{CC}\end{array}$ & Rod & Porous & $\begin{array}{l}+ \\
+\end{array}$ \\
\hline $\begin{array}{c}\text { (Magan and } \\
\text { Ripamonti, } \\
1996)\end{array}$ & $\begin{array}{l}\text { Baboon; } \\
\text { IM }\end{array}$ & 90 & HA & Disc & Porous & + \\
\hline $\begin{array}{c}\text { (Ripamonti, } \\
\text { 1996) }\end{array}$ & $\begin{array}{c}\text { Dog, } \\
\text { Baboon, } \\
\text { Rabbit; } \\
\text { IM }\end{array}$ & 90 & HA & Rod & Porous & $\begin{array}{l}+ \\
+ \\
+\end{array}$ \\
\hline \multirow[t]{2}{*}{$\begin{array}{c}\text { (Yang et al., } \\
\text { 1996) }\end{array}$} & $\begin{array}{c}\text { Rat, } \\
\text { Rabbit, } \\
\text { Goat; } \\
\text { IM, SC } \\
\end{array}$ & $\begin{array}{c}15^{\perp} / 30^{\perp} / 45 / \\
60 / 90 / 120 \\
\text { implanted only }\end{array}$ & \multirow[t]{2}{*}{ 63HA/37TCP } & \multirow[t]{2}{*}{ Cylinder } & \multirow[t]{2}{*}{ Porous } & - \\
\hline & $\begin{array}{l}\text { Dog, Pig; } \\
\text { IM, SC }\end{array}$ & $\begin{array}{l}\text { in dogs and } \\
\text { rabbits }\end{array}$ & & & & + \\
\hline
\end{tabular}


Table 1. (Continued. Part 2)

\begin{tabular}{|c|c|c|c|c|c|c|}
\hline \multicolumn{7}{|c|}{ Calcium Phosphate Ceramics } \\
\hline $\begin{array}{c}\text { (Yang et al., } \\
1997 \text { ) }\end{array}$ & Dog; IM & $\begin{array}{c}7 / 15 / 30 / \\
45 / 60 / 90 / 120\end{array}$ & $65 \mathrm{HA} / 35 \beta \mathrm{TCP}$ & Cylinder & Porous & + \\
\hline \multirow[t]{2}{*}{$\begin{array}{c}\text { (Yuan et al., } \\
\text { 1998) }\end{array}$} & \multirow[t]{2}{*}{ Dog; IM } & $\begin{array}{c}90 / 180 \\
30 / 45 / 60 / \\
90 / 180 \\
30 / 45 / 90 / 150 / \\
180 \\
30 / 45 / 60 \\
30 / 45 / 150\end{array}$ & $\begin{array}{c}\mathrm{HA}(\mathrm{I}) \\
\mathrm{HA}_{\mathrm{ST} 2}(\mathrm{II}) \\
\mathrm{HA}_{\mathrm{ST} 1}(\mathrm{II}) \\
\mathrm{HA} / \mathrm{TCP} \\
\\
\alpha \mathrm{TCP} \\
\beta \mathrm{TCP}\end{array}$ & Cylinder & \multirow[t]{2}{*}{ Porous } & $\begin{array}{l}- \\
+ \\
+ \\
+ \\
+ \\
+\end{array}$ \\
\hline & & $\begin{array}{c}37 / 60 / 180 \\
90 / 180\end{array}$ & $\alpha \mathrm{TCP} / \mathrm{DCPD} / \mathrm{HA}$ & $\begin{array}{c}\text { PH CMT } \\
\text { CMT paste }\end{array}$ & & $\begin{array}{l}+ \\
+\end{array}$ \\
\hline $\begin{array}{c}\text { (Yuan et al., } \\
1999)\end{array}$ & Dog; IM & $90 / 180$ & $\begin{array}{l}\text { HA I } \\
\text { HA II }\end{array}$ & Rod & Porous & $\begin{array}{l}+ \\
-\end{array}$ \\
\hline $\begin{array}{c}\text { (Ripamonti et } \\
\text { al., 1999) }\end{array}$ & $\begin{array}{l}\text { Baboon; } \\
\text { IM }\end{array}$ & $30 / 90$ & $\begin{array}{c}\text { HA I } \\
\text { HA II } \\
\text { HA III } \\
\text { HA IV } \\
\text { HA V }\end{array}$ & Rod & Porous & $\begin{array}{l}+ \\
+ \\
+ \\
+ \\
+\end{array}$ \\
\hline $\begin{array}{c}\text { (Yuan et al., } \\
\text { 2000) }\end{array}$ & Dog; IM & $\begin{array}{c}90 / 180 \\
30 / 60 / 180 \\
\end{array}$ & $\begin{array}{l}\mathrm{HA} / \alpha \mathrm{TCP} / \mathrm{DCPD} \\
\mathrm{HA} / \alpha \mathrm{TCP} / \mathrm{DCPD}\end{array}$ & $\begin{array}{c}\text { CMT paste } \\
\text { PH CMT paste }\end{array}$ & Porous & $\begin{array}{l}+ \\
+ \\
+\end{array}$ \\
\hline $\begin{array}{c}\text { (Yuan et al., } \\
\text { 2001a) }\end{array}$ & Dog; IM & $30 / 45 / 150$ & $\begin{array}{l}\alpha \mathrm{TCP} \\
\beta \mathrm{TCP}\end{array}$ & Disc & Porous & $\begin{array}{l}- \\
+\end{array}$ \\
\hline $\begin{array}{c}\text { (Yuan et al., } \\
\text { 2001e) }\end{array}$ & Dog; IM & 913 & $\begin{array}{c}\text { HA } \\
63 \mathrm{HA} / 37 \beta \mathrm{TCP} \\
\beta \mathrm{TCP} \\
\alpha \mathrm{TCP}\end{array}$ & Disc & Porous & $\begin{array}{l}+ \\
+ \\
- \\
-\end{array}$ \\
\hline $\begin{array}{l}\text { (Eid et al., } \\
\text { 2001) }\end{array}$ & Rat; SC & 7 & $\begin{array}{c}\text { HA } \\
\beta \mathrm{TCP} \\
65 \mathrm{HA} / 35 \beta \mathrm{TCP}\end{array}$ & Particles & NM & $\begin{array}{l}- \\
- \\
-\end{array}$ \\
\hline $\begin{array}{c}\text { (Kurashina et } \\
\text { al., 2002) }\end{array}$ & $\begin{array}{l}\text { Rabbit; } \\
\text { IM }\end{array}$ & 120 & $\begin{array}{c}\text { 70HA/30TCP } \\
\text { 20HA/80TCP } \\
\text { TCP }\end{array}$ & Rod & Porous & $\begin{array}{l}+ \\
- \\
-\end{array}$ \\
\hline
\end{tabular}

i.e. the phenomenon by which a biomaterial elicits or modulates biological activity (Williams, 1999). However, details of the processing parameters are often missing in publications on osteoinductive materials; furthermore, the level to which material properties can be controlled using classical methods of preparation remains limited. Therefore, in an attempt to draw conclusions on the properties which render a material osteoinductive, one is dependent on the description of physico-chemical properties of the end product. Furthermore, a comparison should always be made in light of the experimental scenario in which osteoinductive potential is investigated - a topic which will be discussed in the next section of this review. Table 1 therefore contains information about the material properties which so far have been suggested to play a role in osteoinduction: chemical composition, overall geometry of the implant and porosity. Microstructural surface properties, including grain size, microporosity, surface roughness and specific surface area have been suggested as critical factors in osteoinduction (Yamasaki and Sakai, 1992; Yuan et al., 1999; Habibovic et al., 2005; Yuan et al., 2010). However, these properties have not been described for majority of the materials in Table 1, which is why they were excluded. We will, however, discuss in detail the importance of microstructural surface properties - based on the existing literature.

\section{Influence of Chemical Composition}

As already mentioned, the majority of materials so far described as osteoinductive contain calcium phosphate. Some of the materials that do not contain calcium phosphate, such as titanium, have been shown to calcify when exposed to simulated body fluid (Fujibayashi et al., 2004; Takemoto et al., 2005), and are therefore expected 
Table 1. (Continued. Part 3)

\begin{tabular}{|c|c|c|c|c|c|c|}
\hline \multicolumn{7}{|c|}{ Calcium Phosphate Ceramics } \\
\hline \multirow{2}{*}{$\begin{array}{l}\text { (Yuan et al., } \\
\text { 2002) }\end{array}$} & \multirow{2}{*}{ Goat; IM } & \multirow{2}{*}{84} & HA & Cube & Porous & - \\
\hline & & & $80-90 \mathrm{HA} / 20 \pm 10 \beta$ ТСР & Cube & Porous & + \\
\hline $\begin{array}{l}\text { (Gosain et al., } \\
\text { 2002) }\end{array}$ & $\begin{array}{l}\text { Sheep; } \\
\text { IM,SC }\end{array}$ & 365 & $\begin{array}{c}60 \mathrm{HA} / 40 \beta T C P \\
60 \mathrm{HA} / 40 \beta T C P \\
20 \mathrm{HA} / 80 \beta T C P \\
\text { HA } \\
\text { HA } \\
\end{array}$ & $\begin{array}{c}\text { Disc } \\
\text { CMT paste Disc } \\
\text { CMT paste Disc } \\
\text { Disc } \\
\text { CMT paste Disc } \\
\end{array}$ & Porous & $\begin{array}{l}+ \\
+ \\
+ \\
+ \\
+\end{array}$ \\
\hline $\begin{array}{c}\text { (Habibovic et } \\
\text { al., 2005) }\end{array}$ & Goat; IM & $42 / 84$ & $\begin{array}{c}\mathrm{HA}_{\mathrm{ST} 1} \\
\mathrm{HA}_{\mathrm{ST} 2} \\
12 \mathrm{HA} / 88 \beta \mathrm{TCP}_{\mathrm{ST} 3} \\
12 \mathrm{HA} / 88 \beta \mathrm{TCP}_{\mathrm{ST} 1} \\
12 \mathrm{HA} / 88 \beta \mathrm{TCP}_{\mathrm{ST} 4}\end{array}$ & Cylinder & Porous & $\begin{array}{l}+ \\
- \\
+ \\
+ \\
+\end{array}$ \\
\hline $\begin{array}{c}\text { (Le } \\
\text { Nihouannen } \\
\text { et al., 2005) }\end{array}$ & Sheep; IM & 180 & $60 \mathrm{HA} / 40 \beta \mathrm{TCP}$ & Granules & Porous & + \\
\hline $\begin{array}{c}\text { (Habibovic et } \\
\text { al., 2006a) }\end{array}$ & $\begin{array}{l}\text { Goat; } \\
\text { IM,SC }\end{array}$ & 84 & $\begin{array}{c}80 \mathrm{HA} / 20 \beta \mathrm{TCP}_{\mathrm{ST} 1} \mathrm{I} \\
60 \mathrm{HA} / 40 \beta \mathrm{TCP}_{\mathrm{ST} 2} \mathrm{I} \\
70 \mathrm{HA} / 30 \beta \mathrm{TCP} \text { II } \\
70 \mathrm{HA} / 30 \beta \mathrm{TCP} \mathrm{II} \\
\mathrm{CA} \\
\end{array}$ & Cylinder & Porous & $\begin{array}{l}+ \\
- \\
- \\
+ \\
-\end{array}$ \\
\hline $\begin{array}{c}\text { (Habibovic et } \\
\text { al., 2006c) }\end{array}$ & Goat; IM & 90 & $\begin{array}{l}80 \mathrm{HA} / 20 \beta \mathrm{TCP} \\
\text { ST1 } \\
80 \mathrm{HA} / 20 \beta \mathrm{TCP}_{\text {ST2 }}\end{array}$ & Disc & Porous & $\begin{array}{l}+ \\
+\end{array}$ \\
\hline $\begin{array}{c}\text { (Kondo et al., } \\
\text { 2006) }\end{array}$ & Dog; IM & $\begin{array}{c}14 / 28 / 42 / 56 / \\
112 / 168\end{array}$ & $\beta \mathrm{TCP}$ & Block & Porous & + \\
\hline \multirow[b]{2}{*}{$\begin{array}{c}\text { (Yuan et al., } \\
\text { 2006b) }\end{array}$} & Rat; IM & & $\begin{array}{c}\text { HA } \\
62 \mathrm{HA} / 38 \beta \mathrm{TCP} \\
\end{array}$ & \multirow[b]{2}{*}{ Cylinder } & \multirow[b]{2}{*}{ Porous } & $\begin{array}{l}- \\
-\end{array}$ \\
\hline & $\begin{array}{l}\text { Dog, } \\
\text { Rabbit; } \\
\text { IM } \\
\text { Mouse; } \\
\text { SC }\end{array}$ & 90 & $\begin{array}{c}\text { HA } \\
62 \mathrm{HA} / 38 \beta \mathrm{TCP}\end{array}$ & & & $\begin{array}{c}+ \\
\text { only dog } \\
+\end{array}$ \\
\hline
\end{tabular}

to undergo a similar calcification in vivo. Indeed, in the only publication on osteoinductive polymer, calcification of poly-HEMA in vivo was observed before heterotopic bone formation occurred (Winter, 1970). These data suggest that presence of a calcium phosphate source is a prerequisite for heterotopic bone formation to occur. This observation is not surprising, as bioactivity in terms of osteoconduction in an orthotopic environment has long been recognised for calcium phosphate materials. The liberation of $\mathrm{Ca}^{2+}, \mathrm{PO}_{4}^{3-}, \mathrm{HPO}_{4}^{2-}$ from the material into the surroundings may increase the local supersaturation of the biologic fluid - causing precipitation of carbonated apatite that incorporates calcium-, phosphate- and other ions $\left(\mathrm{Mg}^{2+}, \mathrm{Na}^{+}, \mathrm{CO}_{3}{ }^{2-}\right)$, as well as proteins, and other organic compounds (Habibovic et al., 2005; LeGeros, 2008). The dissolution part of the process is missing in the materials that initially do not contain calcium phosphate; however, their physico-chemical properties are such that they provide nucleation sites for the deposition of a biological apatite layer, containing organics. It is plausible that similar events occur heterotopically, facilitating bone apposition, but whether precipitation / dissolution-reprecipitation events are also responsible for induction of osteogenic differentiation remains to be elucidated. Related to the expected influence of calcium phosphates, the in vivo degradation behaviour of different osteoinductive ceramics requires further discussion. As can be extracted from Table 1, the largest number of studies has been performed with implants consisting of HA, $(\alpha-$ or $\beta-)$ TCP, and the mixtures of the two, BCP. In addition, in a few studies, osteoinduction was also shown to occur in DCPA- and DCPD-cements, carbonated apatite (CA) ceramics and 
Table 1. (Continued. Part 4)

\begin{tabular}{|c|c|c|c|c|c|c|}
\hline \multicolumn{7}{|c|}{ Calcium Phosphate Ceramics } \\
\hline $\begin{array}{c}\text { (Yuan et al., } \\
\text { 2006a) }\end{array}$ & Dog; IM & $\begin{array}{c}7 / 14 / 21 / 30 / 45 / \\
60 / 90 / \\
180 / 360\end{array}$ & $\begin{array}{c}\text { HA } \\
62 \mathrm{HA} / 38 \beta \mathrm{TCP}\end{array}$ & Cylinder & Porous & $\begin{array}{l}+ \\
+\end{array}$ \\
\hline $\begin{array}{c}\text { (Bodde et al., } \\
\text { 2007) }\end{array}$ & Goat; SC & $90 / 180$ & $\mathrm{CP}(61 \% \alpha \mathrm{TCP})$ & CMT cylinder & Porous & - \\
\hline \multirow{3}{*}{$\begin{array}{c}\text { (Ripamonti et } \\
\text { al., 2007) }\end{array}$} & \multirow{3}{*}{$\begin{array}{l}\text { Baboon; } \\
\text { IM }\end{array}$} & \multirow{3}{*}{$90 / 180$} & \multirow{3}{*}{$\begin{array}{c}\text { HA } \\
\text { 77HA/33ßТCP } \\
\text { HA } \\
\text { HA } \\
\end{array}$} & Disc & \multirow{3}{*}{$\begin{array}{l}\text { concavities on } \\
\text { the surface }\end{array}$} & $\begin{array}{l}+ \\
+\end{array}$ \\
\hline & & & & Disc (coarse*) & & + \\
\hline & & & & Disc (fine*) & & + \\
\hline \multirow{2}{*}{$\begin{array}{c}\text { (Habibovic et } \\
\text { al., 2008a) }\end{array}$} & \multirow{2}{*}{ Goat; IM } & \multirow{2}{*}{84} & DCPD & Cube & $\begin{array}{c}\text { Open and } \\
\text { closed channels }\end{array}$ & + \\
\hline & & & DCPA & Cube & $\begin{array}{c}\text { Open and } \\
\text { closed channels }\end{array}$ & + \\
\hline $\begin{array}{c}\text { (Habibovic et } \\
\text { al., 2008b) }\end{array}$ & Goat; IM & 84 & $\begin{array}{c}80 \mathrm{HA} / 20 \beta \mathrm{TCP}_{\text {ST1 }} \\
80 \mathrm{HA} / 20 \beta \mathrm{TCP}_{\text {ST2 }} \\
70 \mathrm{HA} / 30 \beta \mathrm{TCP}_{\text {ST3 }} \\
70 \mathrm{HA} / 30 \beta \mathrm{TCP}_{\text {ST3 }}+\mathrm{PLA} \\
\mathrm{HA} \\
\mathrm{CA}\end{array}$ & Cylinder & Porous & $\begin{array}{l}+ \\
- \\
+ \\
+ \\
- \\
-\end{array}$ \\
\hline $\begin{array}{l}\text { (Ripamonti et } \\
\text { al., 2008) }\end{array}$ & $\begin{array}{l}\text { Baboon; } \\
\text { IM }\end{array}$ & $90 / 365$ & 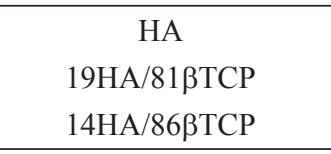 & Disc & $\begin{array}{l}\text { concavities on } \\
\text { the surface }\end{array}$ & $\begin{array}{l}+ \\
+ \\
+\end{array}$ \\
\hline $\begin{array}{c}\text { (Nasu et al., } \\
\text { 2009) }\end{array}$ & Dog; IM & $21 / 42 / 84$ & $\beta$ ТСР & Cylinder & Porous & + \\
\hline $\begin{array}{l}\text { (Ripamonti et } \\
\text { al., 2009) }\end{array}$ & $\begin{array}{l}\text { Baboon; } \\
\text { IM }\end{array}$ & $60 / 90 / 365$ & $\begin{array}{c}5 \mathrm{HA} / 95 \mathrm{CC} \\
13 \mathrm{HA} / 87 \mathrm{CC} \\
\text { HA }\end{array}$ & Rod & Porous & $\begin{array}{l}+ \\
+ \\
+\end{array}$ \\
\hline $\begin{array}{c}\text { (Ripamonti et } \\
\text { al., 2010) }\end{array}$ & $\begin{array}{c}\text { Baboon; } \\
\text { IM }\end{array}$ & 90 & $7 \mathrm{HA} / 93 \mathrm{CC}$ & Rod & Porous & + \\
\hline $\begin{array}{c}\text { (Habibovic et } \\
\text { al., 2010) }\end{array}$ & $\begin{array}{l}\text { Goat; } \\
\text { IM }\end{array}$ & 84 & $\begin{array}{l}\text { CA I } \\
\text { CA II }\end{array}$ & Disc & Porous & $\begin{array}{l}+ \\
-\end{array}$ \\
\hline $\begin{array}{c}\text { (Yuan et al., } \\
\text { 2010) }\end{array}$ & $\begin{array}{l}\text { Sheep; } \\
\text { IM }\end{array}$ & 84 & $\begin{array}{c}10 \mathrm{HA} / 90 \beta \mathrm{TCP} \\
\text { ST1 } \\
10 \mathrm{HA} / 90 \beta \mathrm{TCP} \\
\text { ST2 } \\
\text { TCP }\end{array}$ & Particles & Porous & $\begin{array}{l}+ \\
+ \\
+ \\
+\end{array}$ \\
\hline
\end{tabular}

OCP coatings, as well as in some calcium pyrophosphates. It is well known that dissolution properties of calcium phosphates are phase-dependent (Elliot, 1994), and in some studies, a direct comparison was made between implants with varying chemical composition. For example, in one of our studies, we compared the performance of an HA and a BCP ceramic, produced at equal conditions, in order to keep other material properties similar (Figs. 2A,B). These were implanted intramuscularly in goats and after 6 weeks, bone incidence was higher in the BCP ceramic containing the more soluble TCP, than in the HA ceramic, and so was the amount of bone induced (Figs. 2D,E) (Habibovic et al., 2005). In two other studies, higher osteoinductive potential was also observed for the ceramic containing resorbable $\beta$-TCP as compared to pure HA (Yuan et al., 2006a; Yuan et al., 2006b). However, in the study by Kurashina and colleagues in rabbits, an increase in the amount of TCP had a negative effect on osteoinduction (Kurashina et al., 2002). These data show that the calcium phosphate phase, and the associated degradation behaviour, cannot be appointed as a determinant for osteoinduction to occur - without taking into account other material properties. Indeed, as already mentioned, the materials that initially do not contain calcium phosphate, but possess the ability to calcify in vitro and in vivo, are also able to induce heterotopic bone formation, though to a lesser extent and 
Table 1. (Continued. Part 5)

\begin{tabular}{|c|c|c|c|c|c|c|}
\hline \multicolumn{7}{|c|}{ Calcium phosphate coatings } \\
\hline $\begin{array}{l}\text { (de Bruijn et } \\
\text { al., 2000) }\end{array}$ & Dog; IM & 90 & $\begin{array}{c}\text { Ta } \\
\text { Ta OCP-coated }\end{array}$ & Cylinder & Porous & \\
\hline $\begin{array}{c}\text { (Barrere et al., } \\
\text { 2003) }\end{array}$ & Goat; IM & $84 / 168$ & $\begin{array}{c}\text { Ti6Al4V OCP-coated } \\
\text { Ti6Al4V } \\
\text { Ta OCP-coated } \\
\text { Ta }\end{array}$ & Cylinder & Porous & $\begin{array}{l}+ \\
- \\
+ \\
-\end{array}$ \\
\hline $\begin{array}{c}\text { (Habibovic et } \\
\text { al., 2004) }\end{array}$ & Goat; IM & $42 / 84$ & $\begin{array}{c}\text { Ti6Al4V } \\
\text { Ti6Al4V OCP-coated }\end{array}$ & Cylinder & Porous & $\begin{array}{l}- \\
+\end{array}$ \\
\hline \multicolumn{7}{|c|}{ Other Ceramics } \\
\hline $\begin{array}{c}\text { (Selye et al., } \\
\text { 1960) }\end{array}$ & $\begin{array}{l}\text { Rat; } \\
\text { SC }\end{array}$ & 60 & Pyrex $^{\circledR}$ & Disc & Hollow & + \\
\hline $\begin{array}{c}\text { (Yuan et al., } \\
1998)\end{array}$ & Dog; IM & $37 / 60 / 180$ & $\mathrm{TiO}_{2}$ & Cylinder & Porous & - \\
\hline $\begin{array}{l}\text { (Yuan et al., } \\
\text { 2001c) }\end{array}$ & Dog; IM & 90 & $\mathrm{Al}_{2} \mathrm{O}_{3}$ & Cylinder & Porous & + \\
\hline $\begin{array}{c}\text { (Yuan et al., } \\
\text { 2001b) }\end{array}$ & Dog; IM & 90 & Bioglass $^{\circledR}$ & Cylinder & Porous & + \\
\hline \multicolumn{7}{|c|}{ METALS } \\
\hline \multirow{2}{*}{$\begin{array}{l}\text { (Fujibayashi et } \\
\text { al., 2004) }\end{array}$} & \multirow{2}{*}{ Dog; IM } & \multirow{2}{*}{$90 / 360$} & $\begin{array}{c}\mathrm{Ti} \\
\text { Ti chemically treated }\end{array}$ & Block & \multirow{2}{*}{ Porous } & $\begin{array}{l}- \\
+ \\
\end{array}$ \\
\hline & & & $\begin{array}{c}\text { Ti } \\
\text { Ti chemically treated }\end{array}$ & Mesh Cylinder & & - \\
\hline $\begin{array}{l}\text { (Takemoto et } \\
\text { al., 2005) }\end{array}$ & Dog; IM & $\begin{array}{c}90 / 180 / \\
360\end{array}$ & $\begin{array}{c}\text { Alkali-heat treated } \mathrm{Ti} \\
\text { Water/Alkali-heat } \\
\text { treated } \mathrm{Ti} \\
\text { Dilute } \mathrm{HCl} / \text { Alkali-heat } \\
\text { treated } \mathrm{Ti}\end{array}$ & Cylinder & Porous & $\begin{array}{l}+ \\
+\end{array}$ \\
\hline \multicolumn{7}{|c|}{ HYBRIDS/COMPOSITES } \\
\hline (Li et al., 2007) & Goat; IM & 84 & $\begin{array}{c}\text { Ti6Al4V } \\
\text { Ti6Al4V + BCP hybrid }\end{array}$ & $\begin{array}{c}\text { BCP Cylinders } \\
\text { inside a Ti6Al4V } \\
\text { cylinder }\end{array}$ & Porous & $\begin{array}{l}- \\
+\end{array}$ \\
\hline $\begin{array}{c}\text { (Hasegawa et } \\
\text { al., 2007) }\end{array}$ & Dog; IM & $\begin{array}{c}30 / 45 / 60 / 90 / \\
180 / 360\end{array}$ & $\begin{array}{c}\text { PDLLA } \\
\text { 70HA/30PDLLA }\end{array}$ & Cylinder & Porous & $\begin{array}{l}- \\
+\end{array}$ \\
\hline $\begin{array}{l}\text { (Barbieri et al., } \\
\text { 2010) }\end{array}$ & Dog; IM & 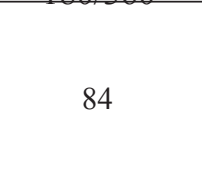 & $\begin{array}{c}\text { PDLLA } \\
\text { 10HA/90PDLLA } \\
\text { 20HA/80PDLLA } \\
\text { 40HA/60PDLLA }\end{array}$ & Block & Porous & $\begin{array}{l}- \\
- \\
- \\
+\end{array}$ \\
\hline \multicolumn{7}{|c|}{ POLYMERS } \\
\hline $\begin{array}{c}\text { (Winter and } \\
\text { Simpson, 1969) }\end{array}$ & Pig; IM & $5 / 10 / 26 / 62$ & Poly-HEMA & Disc & Porous & + \\
\hline
\end{tabular}

after a longer period of time than calcium phosphatecontaining materials. Based on the current knowledge, it is suggested that an increase in in vivo degradation of calcium phosphate materials in general is beneficial for osteoinduction. However, a relatively stable surface is required for the onset of bone formation to take place. In other words, a compromise is to be reached between the level of dissolution/reprecipitation events occurring on the material surface and the rate of material disintegration due to in vivo degradation (Kurashina et al., 2002; Habibovic et al., 2006a). Apart from physico-chemical dissolution / biological apatite precipitation processes, the effect of osteoclastic resorption of biomaterials and therewith accompanied release of calcium ions has also been 


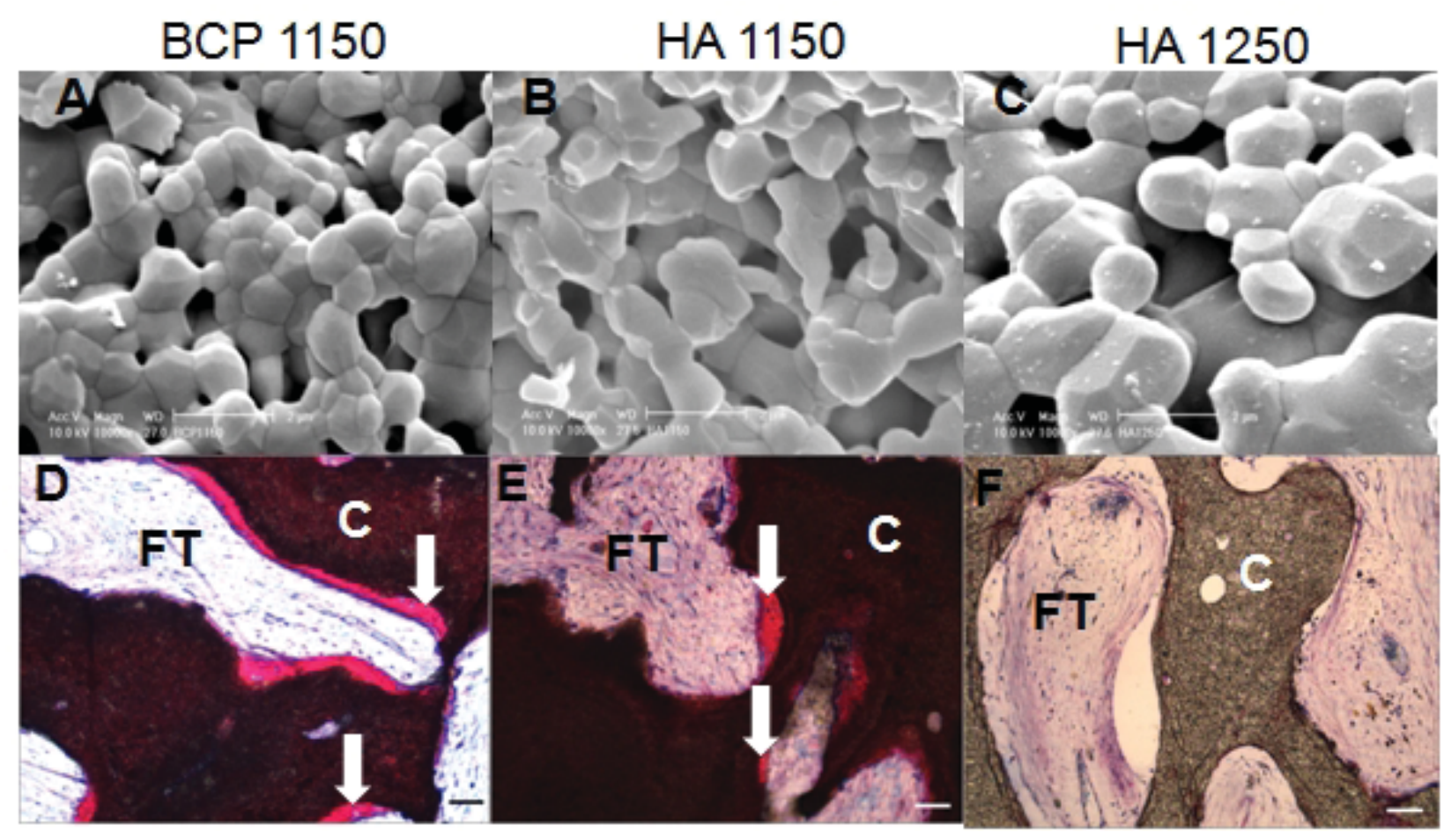

Fig. 2. The effect of chemical composition and microstructure of calcium phosphate ceramics on bone formation. Microstructure of BCP1150 (A), HA1150 (B) and HA1250 (C) is shown by scanning electron microscopy images (scale bar $=2 \mu \mathrm{m}$ ). After six weeks of intramuscular implantation in goats, both BCP1150 and HA1150 containing similar microstructure but different chemical composition, induced bone ( $\mathbf{D}$ and $\mathbf{E}$ ). However, the incidence in BCP was higher (7/10 versus 5/10) and so was the amount of bone induced. In contrast, no bone was observed in HA1250 (F), with fewer micropores and larger grains than the other two ceramics, but with chemical composition identical to that of HA1150. Light microscopy images of stained non-decalcified sections (scale bar $=100 \mu \mathrm{m}$ ). White arrows point towards bone. C: ceramic; FT: fibrous tissue.

suggested to be important in the process of heterotopic bone formation by biomaterials (Ripamonti et al., 2010). What still needs to be determined is whether the free calcium, phosphate, or both ions in the vicinity of a material surface - or the newly formed biological apatite layer on the surface - are the trigger of the osteogenic differentiation of the undifferentiated cells, or simply the template where the onset of bone formation can occur - after the osteogenic differentiation has been triggered by different means.

\section{Influence of Macrostructural Properties}

Apart from the chemical composition of the material, the geometry and macrostructural properties have been shown to play an important role. In the case of macrostructure, the most striking example is the importance of porosity. Bone formation has never been observed on a dense sintered ceramic, that does not degrade in vivo, whereas a ceramic with the same chemical composition, but containing pores, induced bone formation (Yamasaki and Sakai, 1992; Klein et al., 1994;). Generally, the importance of pores inside bone graft substitutes is related to the invasion of the material by blood vessels, that bring along nutrients and oxygen, sustaining therefore the metabolism of cells inside the scaffold (Muschler et al., 2004). In the case of osteoinductive materials, blood vessels can have the added function of bringing along cells with the capacity to differentiate into osteoblasts - which will be discussed in more detail in the section on potential mechanisms behind osteoinduction. Bodde and co-workers suggested that the pore size of the calcium phosphate cement cylinders in their study might have been too small (average $150 \mu \mathrm{m}$ ), when compared to other studies, which could explain why bone formation was not observed after 90 or 180 days of implantation under the skin of goats. They also observed that implant integrity was lost 3 months after implantation and hypothesised that this collapsing of the porous structure might have prevented nutrient supply and decreased the available adsorption areas for protein attachment, cellular adhesion and differentiation (Bodde et al., 2007). In the study by Fujibayashi and colleagues, titanium blocks with predefined porous structure were able to induce bone formation in dogs, in contrast to titanium fibre meshes, surface-treated in the same way (Fujibayashi et al., 2004). The importance of a sustainable macrostructure was also appointed by Gosain and co-workers, who did find bone formation after implantation of a calcium phosphate cement paste. But, they also observed that the rate of material replacement by the newly formed bone increased when macropores were introduced into cementpaste forms of HA - by increasing the ratio TCP/HA. 

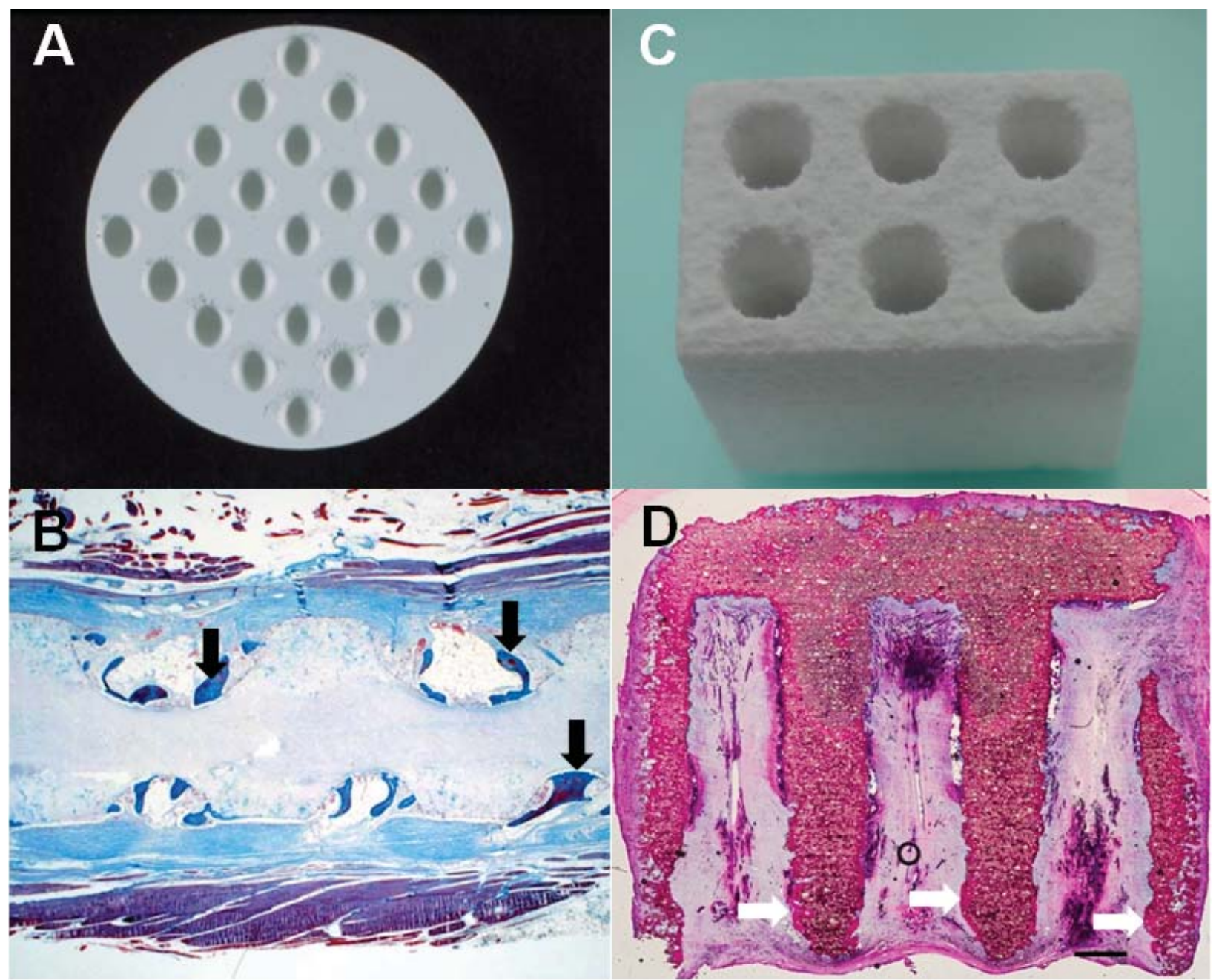

Fig. 3. Heterotopic bone formation is influenced by the geometry of the implant. HA implants (Ø $20 \mathrm{~mm}$, height 4 $\mathrm{mm})$, containing concavities (Ø1600 $\mu \mathrm{m}$, depth $800 \mu \mathrm{m})($ A) were implanted intramuscularly in the baboon. Bone formation was observed after 90 days only in the concave surfaces of the implant (B). DCPA cement implants $\left(11.5 \times 8 \times 10 \mathrm{~mm}^{3}\right)$ containing channels $(\varnothing 2.5 \mathrm{~mm}$, depth $8 \mathrm{~mm})$, open on one and closed on the opposite side of the implant (C) were implanted intramuscularly in the goat and after 12 weeks bone formation occurred only inside the channels, close to the channel opening (D). Black and white arrows point towards bone in B and D respectively. A and $\mathbf{B}$ adapted from (Ripamonti et al., 1999; Ripamonti, 2000). Scale bar $=1 \mathrm{~mm}$.

They also concluded that in HA ceramic, with predefined macroporous structure, more heterotopic bone formation was formed than in HA cements - which at the time of implantation did not contain pores (Gosain et al., 2002). In one of our studies, it was observed that disintegration of porous macrostructure of the ceramic - due to mechanical fracture - prevented bone formation (Habibovic et al., 2006a). In the osteoinductive materials described so far, bone formation was always observed in the pores, and never on the implant periphery or distant from the implant, as is often the case with osteoinduction by BMPs (Liu et al., 2005; Yuan et al., 2010), again emphasising the importance of porous structure.

Besides the presence of pores with suitable dimensions, geometry of the implant has been shown to be important in osteoinduction. In a study by Ripamonti and co-workers, HA ceramic rods and discs containing concavities (Fig. $3 \mathrm{~A})$, varying in height and diameter size, were implanted in the muscle of baboons. The authors observed that bone formation always started in the concave and never on the convex spaces (Fig. 3B), suggesting that some geometries could be more optimal than others in concentrating BMP and stimulating angiogenesis, as this may be a prerequisite for osteogenesis (Ripamonti et al., 1999; Ripamonti et al., 2000). We also observed that, after implanting bulk cement of DCPA containing channels (Fig. 3C), bone was mainly formed in the interior of the peripheral channels, close to their openings, after remaining for twelve weeks in the muscle of goats (Fig. 3D) (Habibovic et al., 2008a). Le Nihouannen and colleagues observed heterotopic bone formation between microporous particles of a BCP ceramic implanted intramuscularly in sheep (Le Nihouannen et al., 2005), which reinforces the idea that "protective" areas, such as pores, concavities or channels, are beneficial for bone formation.

In order to develop an osteoinductive material, we are of opinion that one ought to pay attention to two aspects of macrostructural properties: (1) macrostructure should 


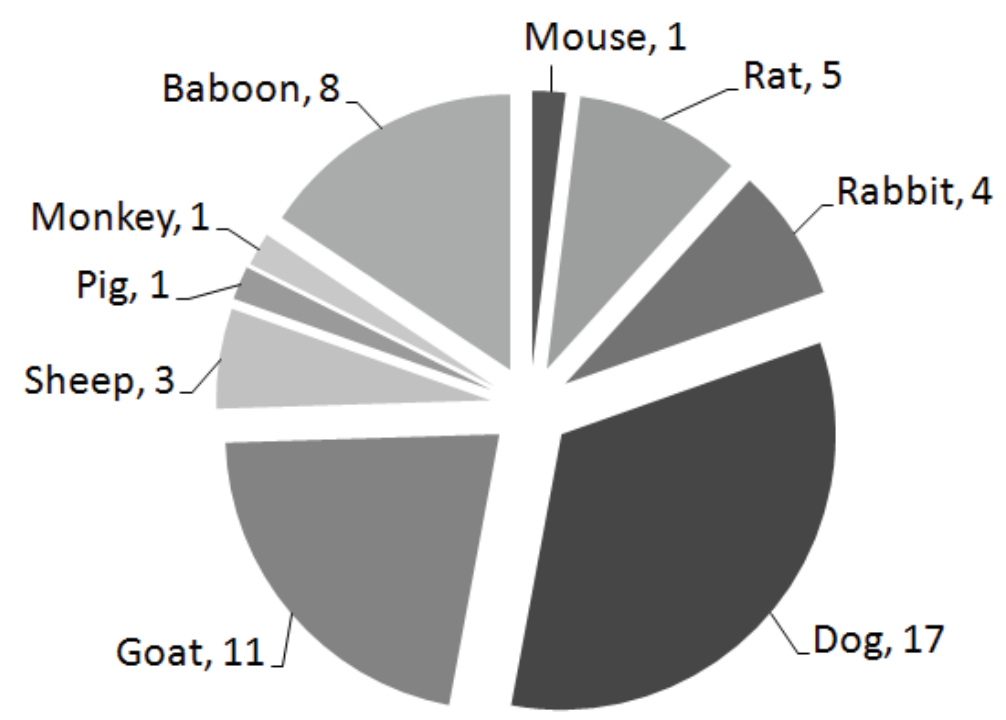

Fig. 4. Number of studies performed per animal model to test calcium phosphate materials for their osteoinductive potential. Data derived from the studies presented in Table 1. The highest number of studies involved dog (Yamasaki and Sakai, 1992; Toth et al., 1993; Klein et al., 1994; Pollick et al., 1995b; Ripamonti, 1996; Yang et al., 1996; Yang et al., 1997; Yuan et al., 1998; Yuan et al., 1999; de Bruijn et al., 2000; Yuan et al., 2000; Yuan et al., 2001a; Yuan et al., 2001e; Kondo et al., 2006; Yuan et al., 2006a; Yuan et al., 2006b; Nasu et al., 2009) and goat (Yang et al., 1996; Yuan et al., 2002; Barrere et al., 2003; Habibovic et al., 2004; Habibovic et al., 2005; Habibovic et al., 2006a; Habibovic et al., 2006c; Bodde et al., 2007; Habibovic et al., 2008a; Habibovic et al., 2008b; Habibovic et al., 2010); the number of published studies involving baboon (Ripamonti, 1991; Ripamonti, 1996; Magan and Ripamonti, 1996; Ripamonti et al., 1999; Ripamonti et al., 2007; Ripamonti et al., 2008; Ripamonti et al., 2009; Ripamonti et al., 2010), sheep (Gosain et al., 2002; Le Nihouannen et al., 2005; Yuan et al., 2010), rabbit (Ripamonti, 1996; Yang et al., 1996; Kurashina et al., 2002; Yuan et al., 2006b), rat (Selye et al., 1960; Klein et al., 1994; Yang et al., 1996; Eid et al., 2001; Yuan et al., 2006b), mouse (Yuan et al., 2006b), monkey (Vargervik, 1992), and pig (Yang et al., 1996) was lower.

be such that there is sufficient supply of nutrients, oxygen and infiltration of cells and tissue, and (2), presence of "protective areas" in the form of pores, channels, concavities, or spaces between individual particles, in which processes leading to heterotopic bone formation can occur without being disturbed by high body fluid refreshments or mechanical forces due to implant movement.

\section{Influence of Surface Structure}

In addition to chemical composition and macrostructural properties, material surface properties at micro- and nanoscale have been shown to be of great importance for osteoinductive potential. Unfortunately, detailed surface characterisation of the materials so far tested for osteoinduction is sparse. Nevertheless, in a few of our studies it has been demonstrated that ceramics with different microstructural properties have different performances when implanted heterotopically. By changing the temperature at which a ceramic is sintered, we were able to vary the grain size and the microporosity of the ceramic, while keeping the chemical composition and the macrostructure constant. We have shown that a decrease in sintering temperature leads to an increase in the number of micropores (defined as pores with a diameter smaller than $10 \mu \mathrm{m}$ ) (Yamasaki and Sakai, 1992; Habibovic et al., 2005; Yuan et al., 2010). This change in surface properties has been shown to have a positive effect on osteoinductive potential of the ceramic. Fig. 2 shows examples of microstructure of the two HA ceramics sintered at $1,150{ }^{\circ} \mathrm{C}$ and $1,250{ }^{\circ} \mathrm{C}$ respectively (Fig. 2B,C) and their behaviour heterotopically (Fig. 2E,F). The number of micropores, together with the grain size, will be reflected in the total surface area. By enlarging the surface area, dissolution/reprecipitation events occurring on the ceramic surface, as well as mineral deposition from the body fluids are expected to be more pronounced - which may be beneficial for osteoinduction to occur. Fellah and colleagues also compared ceramic implants that differed in surface microstructure. By sintering BCP at three different temperatures, materials with the same chemical composition but different microporosity and specific surface area were obtained and implanted both heterotopically, in paraspinal muscle, and orthotopically, inside polytetrafluoroethylene (PTFE) cylinders in a critical-sized femoral defect in goats, to prevent osteoconduction. Autologous bone chips served as control. Bone formation was not observed heterotopically; whereas orthotopically, an increase in microporosity and specific surface area was shown to be beneficial for the amount of bone formed. Whereas no de novo bone formation was formed in cylinders containing bone chips, ceramics 
Physico-chemical and Structural Properties

of Osteoinductive Biomaterials

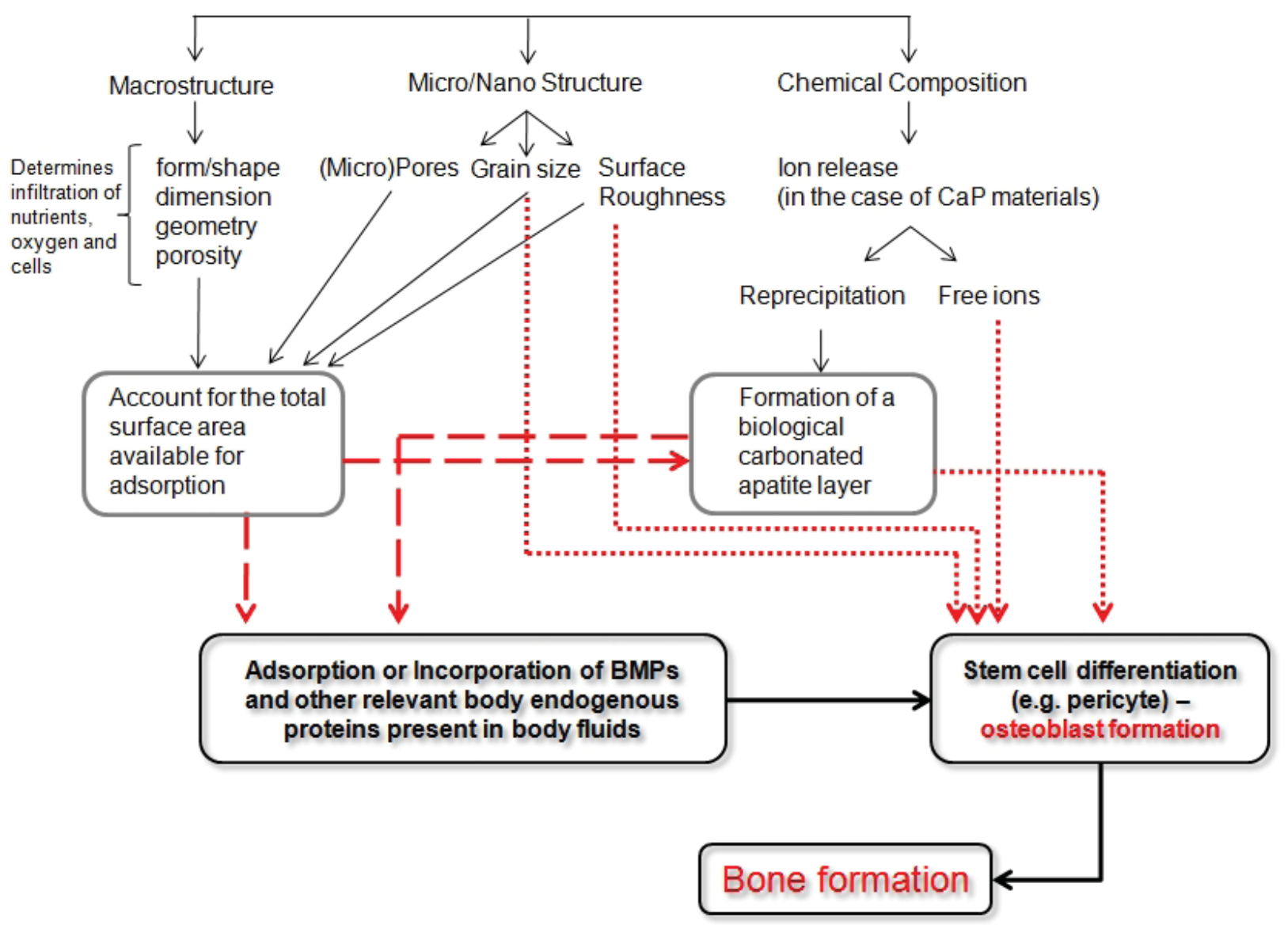

Fig. 5. Schematic summarising hypothesised mechanisms behind osteoinduction by biomaterials. Physico-chemical and/or structural properties of osteoinductive biomaterials may trigger the process of heterotopic bone formation directly or indirectly. Micro and nano structural properties can favour the interaction with BMPs and other essential endogenous proteins that in turn trigger stem cell differentiation into osteoblasts and hence bone formation. But surface topography and inorganic ion release (in the case of calcium phosphate based ceramics), may also be a direct trigger of the process of osteogenic differentiation and bone formation.

- particularly the ones sintered at lower temperatures showed a substantial amount of bone formation (Fellah et al., 2008). Although implantation in the femoral epiphysis - even inside a polymeric cylinder - is not a heterotopic site, this paper does show the effect of surface properties on the formation of new bone. In the study by Fujibayashi and co-workers, it has been shown that porous titanium was only able to induce bone formation heterotopically following a chemical and thermal surface treatment. This treatment, by which the microstructure of the metal was changed, provided the material with the ability to calcify in vitro, and plausibly also in vivo, which was - according to the authors - the driving force behind osteoinduction (Fujibayashi et al., 2004). In addition to the ability to deposit a biological apatite layer on the surface, either through local dissolution/reprecipitation mechanism or from body fluids, adsorption or co precipitation of the growth factors (e.g. BMPs) into the newly formed biological apatite layer from the body fluids are also expected to increase with an increase of the specific surface area - which may be one of the intermediate steps in the initiation of osteogenic differentiation and deposition of de novo bone. Indeed, calcium phosphates, such as HA are well known for their affinity to bind various proteins upon exposure to the in vivo environment (Kandori et al., 1997; Wallwork et al., 2001), including BMPs (Uludag et al., 1999; Boix et al., 2005; Zhou et al., 2007) and an increase of specific surface area may be required to accumulate sufficient amount of BMPs for osteoinduction to be triggered. Apart from this indirect effect of microstructure on the specific surface area and the related ability to bind proteins or deposit a biological mineral layer, the size and the shape of grains could also exert a direct effect on cells involved in osteoinduction. It has been shown that nanosized surface features can act as a direct physical trigger on Mesenchymal Stromal Cells (MSCs) osteogenic differentiation, without additional osteogenic supplements (Dalby et al., 2007). 


\section{Models to Study Osteoinduction}

\section{In vivo models}

Here, we will concentrate on the factors not directly related to materials properties, but known to be of influence when studying osteoinduction: animal model, implantation site, procedure and study duration.

In a number of studies depicted in Table 1, results on bone formation were shown to be animal model dependent. Yang and co-workers tested the performance of sintered BCP ceramics in five different animal models at heterotopic locations, in a single study. Until day 120 , in rats, rabbits and goats, only dense fibrous connective tissue encapsulating the ceramics and loose connective tissue inside the pores were observed - without signs of bone formation. However, in dogs and pigs, bone formation was found in implants retrieved as early as 45 days after implantation. Extensive amounts of bone were found at day 120 mainly in the pores of the materials implanted in pigs (Yang et al., 1996). This study showed that larger animals yielded more bone than smaller ones, with exception of the goat where no bone formation was observed. Also the only osteoinductive polymer, poly-HEMA, was shown to induce bone formation in pigs (Winter and Simpson, 1969), but not in rats, where only calcification of the materials occurred, without bone formation (Winter, 1970). The difference between larger and smaller animals is also seen when evaluating the type of animal models used to perform the studies on osteoinductive materials. Throughout Table 1 , the number of published studies concerning small animals is minimal, and the majority involves large ones. The incidence of animal models in the experimentation on calcium phosphate ceramics is illustrated in Figure 4. Based on the literature search, there is one single study involving mice, four with rabbits and five with rats, whereas most studies were performed in goats (11) and dogs (17). A number of studies have also been performed in non-human primates (9). This scenario contrasts the studies to test the osteoinductive potential of BMPs or osteogenic potential of tissue engineered constructs, which are mainly performed in mice, rats and rabbits. Figure 4 suggests that the incidence of heterotopic bone formation, induced by calcium phosphate ceramics, is higher in large animals as compared to small ones - although we do not know how many (unpublished) studies were actually performed on small animals. Overall, interspecies variation is characterised by the difference in bone induction between small and large animals. But, among large animals differences are also present; for instance, studies involving dogs were in general more successful than those performed in goats. In Table 1, the number of materials marked with a "+" in the "Bone" column is higher in studies in dogs as compared with those in goats. Although being a rough comparison, as no other factors regarding the material or animal model were considered, this suggests that a material tested in a dog has higher chances of inducing bone formation than in a goat. This was evident in the study in which the same material was tested under the same conditions in both animal models (Yang et al., 1996). Trying to explain these interspecies variations would be at best speculative as long as the exact mechanism behind osteoinduction by biomaterials is incompletely understood, but (patho)physiological and genetic differences are expected to play a role.

Apart from the animal model itself, other factors could influence a material's ability to induce bone formation heterotopically, which is why - ideally - the animals should be of the same strain, age, sex and body weight. For example, in a study by Marusic and colleagues, the authors implanted pieces of bone matrix gelatin intramuscularly in mice from 8 different inbred strains. After four weeks, bone formation was observed only in six out of the eight strains. Within mice from each strain, the number of individuals where bone formation was observed varied and the average amount of bone was also different (Marusic et al., 1999), showing that - even among mice of inbred strain - phenotypical differences are such that results are not only strain but also individual dependent. In the case of larger animals, genetic variability will be even higher, as these are always outbred. The effect of age of the animal was apparent in the two studies by Winter and Simpson in pigs, that showed that heterotopic bone formation by a polymeric sponge was only induced in the younger pig (Winter and Simpson, 1969).

Whereas mice, rats, rabbits and sometimes minipigs can be obtained with similar or identical genetic makeups, larger animals - such as dogs, sheep and goats - are relatively heterogeneous with respect to strain, age and body weight (An and Friedman, 1999). In general, when choosing an animal model to study osteoinduction, similar considerations are made as for other orthopaedic applications: ethics, availability, housing requirements, ease of handling, cost, susceptibility to disease and available background data of the animal (An and Friedman, 1999). Considering the described animal model dependence, large animals are usually chosen for assessing osteoinductive potential of biomaterials. Availability is the next important factor determining the choice of the animal model. In the Netherlands, for example, sheep, dogs and goats are used in orthopaedic research, but goats are most widely available. In the majority of studies from our group, we have used young adult Dutch milk goats (age of about 2 years), with the average weight of $65 \pm 10 \mathrm{~kg}$. Although such a group of animals is genetically heterogeneous, we attempted to limit the effect of age, sex and weight, by performing the followup experiments with animals of similar characteristics. Based on papers by others, similar considerations were made in other studies on osteoinductive biomaterials. Despite the fact that we attempted to keep as many parameters of the animal model constant as possible, large variations in the amount and timing of bone induction was observed in different individuals (Habibovic et al., 2006a). This is similar to studies in which biological material was tested (Marusic et al., 1999). It should be mentioned that variations among individuals of the same species are not necessarily a weakness of a study, but potentially tools that will be of help when trying to understand the mechanism behind osteoinduction. We therefore think that in publications on osteoinductive materials, more attention should be paid to the differences observed; for example, 
instead of providing the mean and standard deviation values for the amount of bone formed, one should also provide information about data distribution, outliers, etc.

Another issue that is possibly related to the size of animals used to study osteoinduction, is the size of the implant that can be inserted into an animal. We implanted materials with different dimensions $\left(\varnothing 6.5 \times 5 \mathrm{~mm}^{3}\right.$ versus $\varnothing 6.5 \times 10 \mathrm{~mm}^{3}$ ) in paraspinal muscles of goats. Similar quality of bone was observed in both types, however bone formation had higher incidence in the larger implants $(9 / 10)$ as compared to the smaller ones (7/10). Bone formation also started earlier in larger implants (Habibovic et al., 2006a). It is obvious that, solely based on this single study, no conclusions can be drawn, however, implant size should be taken into consideration when discussing animal model dependent differences in osteoinductive potential of biomaterials.

Several authors have also investigated the osteoinductive capacity of a material, depending on the implantation site and duration of implantation. Ripamonti and colleagues observed no bone formation in coral-derived ceramics, which were partially or fully converted into HA, after 60 and 90 days of intramuscular implantation in Papio ursinus; whereas, after 365 days all ceramics showed heterotopic bone formation (Ripamonti et al., 2009). Yang and co-workers observed bone formation as early as on day 45 after implantation of BCP cylinders in intramuscular pockets of both dogs and pigs; whereas subcutaneously, bone formation was only observed 60 days after implantation. An increase in implantation time in both animal models was also shown to result in an increased amount of bone (Yang et al., 1996). In one of our studies, no bone was found after four months of subcutaneous implantation of a BCP ceramic in goats; whereas intramuscularly, bone was induced in seven out of ten implants in the same animals (Habibovic et al., 2006a). These studies suggest that at intramuscular locations, bone formation occurs more frequently - or at least at a higher rate. The results from Gosain and co-workers contrast these findings. They showed no significant differences in the amount of bone formation in implants of HA and BCP between the subcutaneous and intramuscular location in sheep, after 1 year of implantation (Gosain et al., 2002). The difference in survival time between the studies should however be taken into consideration. It is possible that, at the time of explantation, bone formed intramuscularly had already reached the remodelling phase; whereas subcutaneously, bone - the growth of which was initiated later than intramuscularly - was still in the early formation phase.

Related to the implantation site, the level of injury during implantation is a parameter with enormous implications for the in vivo response to the implanted material. It is the injury and consequent perturbation of homeostatic mechanisms that leads to the cellular cascades of wound healing. Blood-material interactions, provisional matrix formation, acute inflammation, chronic inflammation, granulation tissue formation, foreign body reaction and development of fibrous capsule are the host reactions following injury due to implantation of a material (Anderson, 2000). In the majority of studies reviewed here, implantation was performed in paraspinal muscles - away from bone - where similar host reactions are expected. Although Zaffe argued that skeletal muscle is not a proper site to study osteoinduction by materials (Zaffe, 2005), general agreement is that both subcutis and muscle are sites heterotopic to bone formation, and hence suitable to test osteoinductivity of growth factors and materials. In our studies, after opening the skin, blunt dissections were made to create intramuscular pockets after separate fascia incisions, into which materials were placed separately and secured with non-resorbable sutures. Sufficient distance was kept between individual pockets, to avoid that individual implants could affect each other's behaviour. Pre- and post operative treatment of the animals was performed according to the procedures used for orthotopic implantations.

A note should also be made on the topic of sample analysis following an in vivo study. In the majority of studies discussed so far, histological staining of tissue on two-dimensional sections is performed, often followed by quantification based on image analysis. These are established methods to visualise the characteristics of tissue formed on cellular and matrix level. The fact that the sections are two-dimensional is a disadvantage, especially when quantification is involved - where one can only analyse areas rather than volumes. In addition, depending on the position at which a section is made, one can possibly miss important information. Le Nihouannen and colleagues used X-ray micro-computed tomography $(\mu \mathrm{CT})$ to quantify the volume of both ceramic material and mineralised bone, distinguishing them based on the gray levels (Le Nihouannen et al., 2008). Although insufficient resolution and inaccurate phase identification are known as important limitations of the $\mu \mathrm{CT}$ technique, when studying bone formation in (ceramic) implants, recent studies with high resolution $\mu \mathrm{CT}$ have demonstrated the potential of this technique in the field of bone regeneration (Eniwumide $e t$ al., 2007; Castellani et al., 2009; Jones et al., 2009; Komlev et al., 2010).

A thorough histological analysis, that is more extensive than the analysis of quality and quantity of newly formed bone, can also add to the understanding of mechanism of osteoinduction. Presence of inflammatory signs, such as monocytes, mono- and multi- nucleated-macrophages, lymphocytes or fibrous tissue could indicate if and how the immune system contributes to the mechanism of bone formation by biomaterials. For example, Fellah and colleagues extensively characterised the type of white cells present in histological sections of BCP microparticles of varying sizes explanted from rat muscle. They identified and quantified the presence of macrophages, giant cells and lymphocytes and observed that these amounts varied according to the implanted particle size (Fellah et al., 2007), indicating that macrostructural properties might trigger immune responses accordingly. Similarly, analysis of spatial distribution and quantification of blood vessels inside an implant could provide answers regarding importance of oxygen and nutrient supply as well as cells associated with neovascularisation in osteoinduction.

Based on the published work and our experience, we suggest that large animals, such as goats, sheep, dogs or 
baboons should be used for intramuscular implantation to study material-induced bone formation. Attention should be paid that the group of animals used is controlled for sex, age, weight and - where possible - strain. Considering large differences between individual animals, paired implantations should be performed (comparisons of different materials within each animal of the group). Surgical procedure should be such that minimal damage is caused to the tissue, and the animals should receive the pre- and postoperative treatment according to standard procedures for orthopaedic research. With large animals as animal models, one should be aware that essential biological research tools, such as antibodies, are far less available than for smaller ones - which is one of the delaying factors in the biological comprehension of the mechanism. Therefore, more attention should be paid to methods of histological characterisation and quantification of the tissues formed in and around the implanted material.

\section{In vitro Models and Choice of Cell Type}

In the previous section, we have described the complexity of research involving large animals to study osteoinductive biomaterials. Ideally, simple and reliably predictive in vitro assays should be available to screen the osteoinductive properties of biomaterials; and, at the same time, accelerate the comprehension of the mechanism behind this phenomenon. Unfortunately, development of such an assay is far from trivial. An important question that needs to be answered is which parameters of the complex in vivo environment are relevant to be translated into a simplified in vitro system to make it predictive - including cell source and type, culturing conditions and output parameters? The complexity of this question is also evident from the fact that, despite the established clinical use of DBM for decades, assays that are able to reliably predict osteoinductive capacity of DBM in vivo are still largely missing. Adkisson et al. developed a "rapid quantitative bioassay of osteoinduction" by using SaOS-2 osteosarcoma cells and studied cell proliferation rates under the influence of DBM. However, correlation between cell proliferation and osteoinduction was not strong (Adkisson et al., 2000). Zhang et al. and Wolfinbarger and Zheng used human periosteal cells and human dermal fibroblasts to relate cellular ALP activity to DBM osteoinductivity (Wolfinbarger and Zheng, 1993; Zhang et al., 1997). In these studies, the authors failed to show a clear correlation between in vitro assays and in vivo bone formation. Carnes et al. used an immature osteoprogenitor cell line, 2T9 to investigate the effect of DBM on the cell differentiation (Carnes et al., 1999). They failed to show any effect on differentiation and concluded that there are no soluble factors being released from DBM into the culture medium. Han et al. assessed the ALP activity of the $\mathrm{C} 2 \mathrm{C} 12$ cells in a culture in presence of DBM, and found a correlation with heterotopic bone formation (Han et al., 2003). However, when we repeated a similar study with osteoinductive ceramics, the in vitro ALP expression of $\mathrm{C} 2 \mathrm{C} 12$ cells could not be correlated to the heterotopic bone formation induced by the ceramics (Habibovic et al., 2006b).
When material-cell interactions are studied and different materials in vitro are compared, the materialmedium interactions add an additional variable to the equation. In the case of calcium phosphate containing materials, for example, ion exchange between the material and the medium may significantly modify the composition of the latter, and hence the environment for cells to grow and differentiate. Furthermore, changes that take place in the medium will vary depending on the properties of the material, resulting in a study where same cells are cultured in different environments (Habibovic et al., 2006b), making a comparison difficult and little reliable. These in vitro interactions can be very different from the in vivo material-body fluid interactions, where there is a continuous refreshment of body fluids around the implant.

Although the fact that the situation of a ceramic implanted in, for example, a goat muscle cannot be mimicked in a culture dish, investing into development of simplified predictive systems is necessary to aid the understanding of the mechanism and accelerate the improvement of the existing materials for bone regeneration. In our recent work, we have described an in vitro model with human bone marrow stromal cells (hBMSCs) and four different types of calcium phosphate ceramics: $\mathrm{HA}, \mathrm{BCP}$ sintered at $1,150^{\circ} \mathrm{C}(\mathrm{BCP} 1150)$ and at $1,300{ }^{\circ} \mathrm{C}$ (BCP 1300) and TCP. We showed that after seven days in culture on the different ceramics in osteogenic differentiation medium, genes encoding for proteins characteristic of an osteogenic profile were differentially expressed by hBMSCs. A trend was observed in the degree of differentiation, with cells on TCP exhibiting higher expression of most genes, followed by those on BCP 1150 , BCP 1300 and HA. This trend correlated with the amount of bone obtained when the materials were implanted without cells, intramuscularly in sheep (Yuan et al., 2010). It is to be further investigated whether this system is only valid for the group of ceramics tested in our study, or it is applicable to other osteoinductive materials as well.

Other in vitro models have given insights into the possible role of inflammatory cells on bone formation. Fellah and co-workers investigated the expression of TNF- $\alpha$ and IL- 6 by a mouse macrophage cell line when cultured on BCP particles with different size ranges. They observed that expression of these cytokines was highest when macrophages were cultured on microparticles smaller than $20 \mu \mathrm{m}$, as compared to $40-80 \mu \mathrm{m}$ and 80-200 $\mu \mathrm{m}$ particles. Next, they cultured pre-osteoblast mouse cells in presence of IL- 6 and TNF- $\alpha$ and demonstrated that the expression of some osteogenic markers was higher when cells were cultured in the presence of IL-6 than when cultured in osteogenic medium. Based on these data, the authors attempted to correlate microstructural properties of a ceramic directly with inflammatory response and indirectly, with osteogenic response and hence osteoinduction (Fellah et al., 2010). Studies in which macrophages and pre-osteoblasts are co-cultured on ceramics with different osteoinductive potential would provide a direct insight into the role of inflammation in osteoinduction in vitro. 


\section{The Ability to Induce Bone Formation: Where Does It Originate From?}

We have mentioned before that the mechanism behind osteoinduction by biomaterials is not completely understood yet. Nevertheless, a number of hypotheses have been proposed by different researchers. On the basis of current knowledge of material properties so far shown to be relevant for osteoinduction to occur, and biological processes occurring around and in the material upon implantation in, e.g. a muscle, we will discuss different hypotheses and give our view on the phenomenon.

Host response to a biocompatible material implanted in vascularised tissues such as muscle is associated with the events of injury formation, followed by inflammatory cell infiltration, acute and chronic inflammation, granulation tissue formation and foreign body reaction. In general, the polymorphonuclear leukocytes predominant inflammatory response and the leukocytes/ monocytes predominant chronic inflammatory response resolve quickly, within 2 weeks. The process of granulation tissue formation, characterised by the action of monocytes and macrophages, and the subsequent foreign body reaction - consisting either of fibrous capsule formation or macrophage and foreign body giant cell action - is highly dependent on the chemistry and topographical surface properties of the implanted material (Anderson, 2000). In a number of studies, response to heterotopically implanted osteoinductive materials was followed in time - based on histology. Yang and co-workers studied the host response to a porous BCP ceramic in muscle of dogs 7-45 days post implantation. On day 7, they observed blood clots and some fibrous tissue inside the pores of the ceramic. On day 15 , granulation tissue, with fibroblasts, macrophages and some newly formed blood vessels, was observed. At 30 days, denser fibrous tissue, parallel to the pore walls was observed, with polymorphic cell aggregates in association with capillaries and small venules in the vicinity of ceramic surface - some of which were positive for the ALP staining. Finally, on day 45, presence of similar cell aggregates was obvious; some multinucleated giant cells were found and osteoblasts aligned the newly formed bone, that was in close contact with the ceramic surface (Yang et al., 1997). Yuan and colleagues identified similar processes leading to bone formation as Yang and colleagues upon intramuscular implantation in dogs of an HA and a BCP ceramic between 7 and 360 days of implantation. They observed aggregates of large cuboidal cells on the material surface in close association with capillaries, before osteoblasts were observed - that deposited osteoid - leading to bone apposition, remodelling and bone marrow formation. The sequence of processes observed was similar for the two ceramics. However, they all occurred at an earlier time point in the BCP than in the HA ceramic, and the amount of bone formed in HA was lower than in BCP (Yuan et al., 2006a). Kondo and colleagues showed similar processes upon implantation of $\beta$-TCP in dog dorsal muscles: red blood cells, fibroblast-like spindle-shaped cells, few multinucleated cells and some blood vessels at 14 days, loose connective tissue consisting of sparsely distributed reticular collagen fibrils on day 28 and a larger number of TRAP and Cathepsin-K positive multinucleated cells - and newly formed bone on the ceramic surface after 56 days that continued growing until the last analysis point at 168 days (Kondo et al., 2006). Following intramuscular implantation of HA in baboons for 3, 6 and 9 months, Ripamonti first observed fibrous connective tissue with pronounced cellular and vascular components, then the collagen fibre condensation in fibrous connective tissue at the interface of the HA, and finally morphogenesis of bone - with subsequent remodelling, formation of lamellar bone and differentiation of bone marrow (Ripamonti, 1991). In all these studies, a natural host response to the material implanted in soft tissue was observed. However, in contrast to many others, these materials eventually led to heterotopic bone formation. The main questions that remain to be answered are: (1) what is the identity of the cells which are triggered to differentiate into the osteogenic lineage? (2) what triggers their accumulation on the material surface and subsequent osteogenic differentiation?

Considering the first question, Ripamonti and coworkers - who implanted HA heterotopically in baboons - observed that before and during bone formation, laminin staining (for vascular endothelial cells) was localised around capillaries in close proximity to the ceramic - as well as around individual cells that seemed to migrate out of the vascular compartment (Ripamonti et al., 1993). Yang and colleagues further commented that in dogs, polymorphic cells that appeared first close to capillaries and microvessels were likely to be migrating towards the ceramic and that osteoblast differentiation was occurring directly within the cell clusters which aggregated at the interface with the ceramics - especially where capillaries were in close proximity to the material (Yang et al., 1996). They hypothesised that cells appearing close to the vasculature, those aggregating and those differentiating could be interrelated and could have origin in the proliferation, differentiation or migration of pericytes or endothelial cells.

In the formation of the skeleton, mesenchymal cells aggregate and form condensates of loose mesenchymal tissue, prefiguring the skeletal elements. Within these aggregates, cells may differentiate into osteoblasts, when in association with adequate vascularisation, thereby directly initiating ossification - which eventually results in either compact or cancellous bone (intramembranous bone formation). Alternatively, condensates of mesenchymal cells can differentiate into chondrocytes in an avascular environment, producing cartilage which is eventually replaced by bone (endochondral bone formation) (Van Gaalen et al., 2008). Heterotopic bone formation induced by biomaterials always occurs via the intramembranous pathway; indeed, suggesting the importance of the newly formed blood vessels and the associated cells, such as endothelial cells and pericytes, in the vicinity of the ceramic - as observed in the chronological studies into the process of osteoinduction.

Pericytes derive from multiple cell types and are capable of acquiring various phenotypes (Collett and Canfield, 2005). They are mural cells that lie on the abluminal side of blood vessels, immediately opposed to endothelial cells. They have been reported as capable 
of synthesizing ALP, osteocalcin and formation of colonies that mineralised in vitro (Brighton et al., 1992). Furthermore, they deposit a matrix that resembles the one found in calcified blood vessels (Collett and Canfield, 2005). Using an experimental model of wound repair in the skull, Sato and Urist demonstrated that BMP induced the osteogenic differentiation of pericytes resulting in the formation of chondroid and woven bone (Sato and Urist, 1985). In vivo studies in rats showed that a vascular staining, incorporated in the walls of vessels of the microcirculation that initially stained endothelial cells and pericytes, was found in some of the osteoblasts during bone tissue development, after a small periosteum strip was raised from the femur - suggesting that pericytes are a supplementary source of osteoblasts in periosteal osteogenesis (Diaz-Flores et al., 1992).

More recently, it has been suggested that an ancestor of the MSC is natively associated with the blood vessel wall, and more precisely, belongs to a subset of perivascular cells - although some MSCs may originate in other cell subsets (Crisan et al., 2008; da Silva Meirelles et al., 2008). Furthermore the authors suggested that pericytes are released upon vessel damage or inflammation, to provide activated MSCs that will in turn stimulate tissue-intrinsic progenitors to regenerate the damaged area among other functions. The in vivo data demonstrating close association of heterotopic bone onset on the ceramic surface with capillaries and microvessels, together with our in vitro and in vivo data showing osteogenic response of bone marrow derived MSCs on osteoinductive ceramics (Yuan et al., 2010), has created our working hypothesis that pericytes contribute to the process of bone formation at the surface of an osteoinductive material - either by undergoing the osteogenic differentiation or by providing activated MSCs as osteoprogenitors. Recently, Ripamonti and co-workers postulated that myoendothelial cells in skeletal muscle may be the cells that differentiate into osteoblasts when in contact with osteoinductive biomaterials (Ripamonti et al., 2010). Indeed, clonally derived myoendothelial cells have been shown to differentiate into myogenic, osteogenic and chondrogenic lineage in cell culture (Zheng et al., 2007).

Early work by Urist and colleagues on osteoinduction by DBM and identification of BMPs, as well as their demonstration of BMP-induced osteogenic differentiation of pericytes, logically poses endogenous BMPs as a possible trigger of osteoinduction by biomaterials. By detecting BMP-3 and BMP-7 on the interface of tissueHA substrate, where bone was observed after implantation in the muscle of primates, Ripamonti and co-workers hypothesised that the intrinsic osteoinductivity of these materials is intimately related to BMPs (Ripamonti et al., 1999). The authors proposed that these smart materials act as solid substrata for the adsorption, storage and controlled release of BMPs, for which probably a concentration threshold has to be reached in order to induce bone formation. These ideas are shared by De Groot, who proposed the rational design and development of BMP concentrators that, after implantation in the patient, are capable of concentrating and immobilising the endogenous BMP complex (De Groot, 1998). Nasu and co-workers further showed that injections of an EP4 agonist in animals that received TCP intramuscularly accelerated bone formation, as compared to the control group that received the biomaterial alone, highlighting the role of these materials as BMP concentrators. EP4 is a prostaglandin E2 (PGE2) receptor which has been proven to enhance the effect of rhBMP in a spinal fusion rabbit model, reducing to half the required dose of rhBMP alone (Nasu et al., 2009). Ripamonti and co-workers recently argued the hypothesis that materials may concentrate endogenous BMPs, resulting in turn in heterotopic bone formation, because circulating BMPs are bound to protein carriers which inhibit or reduce the osteogenic activity of BMPs (Ripamonti et al., 2009). Instead, the authors suggested that first, osteoclastic resorption of the osteoinductive substrate occurs, accompanied with release of calcium ions - that in turn stimulate angiogenesis and osteogenic differentiation of stem cells. Upon osteogenic differentiation, stem cells are then suggested to express and secrete BMPs which are incorporated into the biomaterial surface to eventually induce heterotopic bone formation (Ripamonti et al., 2009).

Although it certainly is plausible that endogenous BMPs (either circulating or locally produced by the differentiating cells) are accumulated on the surface of osteoinductive biomaterials, it is difficult to explain why not all materials, or at least all calcium phosphate ceramics - with their high affinity to bind BMPs (Urist et al., 1984; Wang et al., 1988; Luyten et al., 1989) - are osteoinductive. In other words, if BMPs are involved in osteoinduction by biomaterials, their role is - in our opinion - dependent on, or at least related to other processes occurring upon implantation of a material - such as the deposition of a biological apatite layer. The ability of a material to form a biological apatite layer on its surface, either through dissolution/reprecipitation or through nucleation from biological fluids, is namely the only property that is characteristic of all materials so far shown osteoinductive. Deposition of the biological apatite layer is accompanied by the co-precipitation of organic factors such as osteogenic proteins, which may trigger the osteogenic differentiation of the relevant cells; however, if the deposition of the biological apatite does not occur, osteoinduction will not occur either, despite the possible adsorption of osteogenic proteins on the material surface. This is possibly related to the amount of proteins that needs to be accumulated in order for osteoinduction to take place.

Other theories concentrate on a material's ability to trigger secretion of factors leading to bone formation, rather than to their ability to accumulate them on the surface. Endothelial cells are known to express cytokines such as BMP-2, BMP-4 and BMP-7 (Collett and Canfield, 2005), and the expression of BMP-2 and BMP-7 has been shown to be markedly upregulated in response to inflammatory stresses (Cola et al., 2004; Sorescu et al., 2004). This specific inflammatory response of tissues to the osteoinductive ceramics has been proposed by some researchers as the factor that renders a material osteoinductive. Le Nihouannen and co-workers, for example, elaborated that the induction of bone formation by microporous ceramics was intimately related with the inflammatory response. They hypothesised that particles smaller than $5 \mu \mathrm{m}$ are released from the ceramics and provoke an inflammatory reaction, with consequent release 
of cytokines that promote the differentiation of circulating stem cells into osteoblasts (Le Nihouannen et al., 2008). Micrometer sized particles can also be released from other materials, like metals and polymers - as is often seen in cases of periprosthetic osteolysis - which could extend the theory to these classes of materials as well. However, not only particles released from the implants can influence the activity of macrophages but also the surface topography/ roughness. De Bruijn and colleagues suggested the effect of prostaglandin E2 (PGE2) in osteoinduction (De Bruijn et al., 2008). PGE2 is a factor that is produced by macrophages around biomaterials during inflammation phase, in particular on micro-rough surfaces (Refai et al., 2004; Thomsen and Gretzer, 2001). In the study by De Bruijn et al. is was shown that macrophages produced higher quantities of PGE2 in response to micro-rough surfaced HA, unique for osteoinductive materials, as compared to cells cultured on smooth HA surfaces. Furthermore, PGE2 was shown to be chemotactic for hMSCs and to stimulate their osteogenic differentiation (De Bruijn et al., 2008). Based on these findings, the authors proposed that processes leading to heterotopic bone formation start with injury due to implantation. This is followed by inflammation and invasion of the material by macrophages, when osteoinductive stimulates production of inflammatory cytokines - including PGE2, which in turn cause chemotaxis of MSCs, their osteogenic differentiation and eventually bone formation (De Bruijn et al., 2008).

The role of the immune system is also frequently debated in pathologies that involve spontaneous calcification and/ or heterotopic ossification. For example, in a study by Kan and colleagues, it was shown that, when macrophages were depleted in an established mouse model for Fibrodysplasia Ossificans Progressiva in Nse-BMP4 mice, the onset of heterotopic ossification upon tissue injury was delayed and the number of mice that developed ossification decreased. When the Nse-BMP4 mice were lacking mature B and $\mathrm{T}$ lymphocytes, the onset of heterotopic ossification occurred without delays, but the spreading and overall amount of ossification were smaller than in mice with B and $\mathrm{T}$ lymphocytes, suggesting that the adaptive immune system plays a role in spreading of heterotopic ossification. The authors proposed that the macrophage responses to tissue injury stimulate local inducible progenitor cells to differentiate into bone, through accumulation of osteogenic factors including BMPs (Kan et al., 2009). Furthermore, there is an extensive list of signalling pathways involved in bone metabolism that were also described in association with arteries- and/or plaque calcification, such as extracellular matrix proteins (osteopontin, osteonectin, bone sialoprotein), several BMPs, RANK/RANKL and TNF- $\alpha$. However, like for material-induced heterotopic bone formation, questions remain regarding the origin of cells that are involved in mechanisms leading to, for example, plaque ossification: smooth muscle cells, pericytes and circulating progenitor cells are possible candidates for osteoblast precursors and monocytes/ macrophages for osteoclasts (Doherty et al., 2003).

Although inflammation may be relevant for the onset of heterotopic bone formation by biomaterials, one cannot neglect the fact that the time point at which heterotopic bone formation occurs varies among different materials and different animal models between a few weeks and a year (Table 1), which is long after the initial inflammatory response of the tissue to the implanted material, suggesting that other processes also determine the initiation of heterotopic bone formation.

Although no conclusive evidence exists for any of the hypotheses proposed so far for osteoinduction by biomaterials, in the schematic in Fig. 5 we have summarised the processes occurring during and possibly determining osteoinduction by biomaterials.

\section{Future Perspectives}

It is well accepted that certain materials used in bone regeneration are bioactive in terms of osteoconductivity. However, the appreciation of the fact that some of these materials possess intrinsic osteoinductivity by broad audience needs a paradigm shift that can only be achieved with complete comprehension of the mechanism behind this phenomenon (Yuan et al., 2011). And although the mechanism is still not fully understood, in this review we have shown that the knowledge of material properties relevant for osteoinduction has tremendously increased in the past decade, despite the limitations of available models to test osteoinductivity. More importantly, some osteoinductive materials have shown equal performance to that of BMP-2 and autologous bone in a number of clinically relevant orthotopic in vivo models (Yuan et al., 2010). To provide conclusive evidence that osteoinductive biomaterials can act as a valid alternative to autologous bone and osteogenic growth factors, more studies are needed in which a direct comparison is made between bone grafts / various growth factors and bone graft substitutes. Finally, it should be noted that all studies performed so far with osteoinductive biomaterials have been performed in preclinical animal models. Although these models were chosen in such a way that they resembled the clinical situation as closely as possible, only clinical trials will be able to provide the proof for the relevance of osteoinductivity in human patients. In order to accept or reject the existing hypotheses regarding the mechanism of osteoinduction, we are of opinion that the researchers should use the existing knowledge to design materials with closely controlled properties, rather than to rely on the processing parameters, which can only be controlled to a limited extent. By such a rational design, one can vary a single parameter, while keeping the others constant, in order to pinpoint which property or properties are essential for osteoinduction to occur. Furthermore, we believe that investing in novel techniques to identify biological processes occurring upon implantation of an osteoinductive material in vivo may be more efficient than the search for predictive in vitro assays.

\section{Acknowledgements}

The authors gratefully acknowledge the financial support of the TeRM Smart Mix Program of the Netherlands 
Ministry of Economic Affairs and the Netherlands Ministry of Education, Culture and Science (AB) and Innovative Research Incentives Scheme Veni of the Netherlands Organisation for Scientific Research (PH). Hugo Fernandes and Charlène Danoux are acknowledged for critical reading of the manuscript.

\section{References}

Adkisson HD, Strauss-Schoenberger J, Gillis M, Wilkins R, Jackson M, Hruska KA (2000) Rapid quantitative bioassay of osteoinduction. J Orthop Res 18: 503-511.

An YH, Friedman RJ (1999) Animal models of bone defect repair. In: Animals Models in Orthopaedic Research (An YH, Friedman RJ, eds), CRC Press LLC, Boca Raton, FL, USA, pp 241-260.

Anderson J (2000) The cellular cascades of wound healing. In: Bone Engineering (Davies JE, ed), Em squared, Toronto, pp 81-93.

Barbieri D, Renard AJ, de Bruijn JD, Yuan H (2010) Heterotopic bone formation by nano-apatite containing poly(D,L-lactide) composites. Eur Cell Mater 19: 252-261.

Barrere F, van der Valk CM, Dalmeijer RA, Meijer G, van Blitterswijk CA, de Groot K, Layrolle P (2003) Osteogenecity of octacalcium phosphate coatings applied on porous metal implants. J Biomed Mater Res 66A: 779788.

Bertelsen A (1944) Experimental investigations into post-foetal osteogenesis. Acta Orthop Scand 15: 139-181.

Boakye M, Mummaneni PV, Garrett M, Rodts G, Haid $\mathrm{R}$ (2005) Anterior cervical discectomy and fusion involving a polyetheretherketone spacer and bone morphogenetic protein. J Neurosurg Spine 2: 521-525.

Bodde EW, Cammaert CT, Wolke JG, Spauwen PH, Jansen JA (2007) Investigation as to the osteoinductivity of macroporous calcium phosphate cement in goats. J Biomed Mater Res B Appl Biomater 83: 161-168.

Boix T, Gomez-Morales J, Torrent-Burgues J, Monfort A, Puigdomenech P, Rodriguez-Clemente R (2005) Adsorption of recombinant human bone morphogenetic protein RHBMP-2m onto hydroxyapatite. J Inorg Biochem 99: 1043-1050.

Brighton CT, Lorich DG, Kupcha R, Reilly TM, Jones AR, Woodbury RA, 2nd (1992) The pericyte as a possible osteoblast progenitor cell. Clin Orthop Relat Res 275: 287 299.

Carnes DL Jr, De La Fontaine J, Cochran DL, Mellonig JT, Keogh B, Harris SE, Ghosh-Choudhury N, Dean DD, Boyan BD, Schwartz Z (1999) Evaluation of 2 novel approaches for assessing the ability of demineralized freeze-dried bone allograft to induce new bone formation. J Periodontol 70: 353-363.

Castellani C, Zanoni G, Tangl S, van Griensven M, Redl H (2009) Biphasic calcium phosphate ceramics in small bone defects: Potential influence of carrier substances and bone marrow on bone regeneration. Clin Oral Implants Res 20: $1367-1374$.

Cola C, Almeida M, Li D, Romeo F, Mehta JL (2004) Regulatory role of endothelium in the expression of genes affecting arterial calcification. Biochem Biophys Res Commun 320: 424-427.

Collett GD, Canfield AE (2005) Angiogenesis and pericytes in the initiation of ectopic calcification. Circ Res 96: 930-938.

Crisan M, Yap S, Casteilla L, Chen CW, Corselli M, Park TS, Andriolo G, Sun B, Zheng B, Zhang L, Norotte C, Teng PN, Traas J, Schugar R, Deasy BM, Badylak S, Buhring HJ, Giacobino JP, Lazzari L, Huard J, Peault B (2008) A perivascular origin for mesenchymal stem cells in multiple human organs. Cell Stem Cell 3: 301-313.

Da Silva Meirelles L, Caplan AI, Nardi NB (2008) In search of the in vivo identity of mesenchymal stem cells. Stem Cells 26: 2287-2299.

Dalby MJ, Gadegaard N, Tare R, Andar A, Riehle MO, Herzyk P, Wilkinson CD, Oreffo RO (2007) The control of human mesenchymal cell differentiation using nanoscale symmetry and disorder. Nat Mater 6: 997-1003.

Davies JE, Hosseini MM (2000) Histodynamics of endosseous wound healing. In: Bone Engineering (Davies JE, ed), Em squared Inc., Toronto, Canada, pp 1-14.

De Bruijn J, Shankar K, Yuan H, Habibovic P (2008) Osteoinduction and its evaluation. In: Bioceramics and Their Clinical Applications (Kokubo T, ed), Woodhead Publishing Ltd, Cambridge, UK, pp 199-219.

De Bruijn JD, Yuan H, Dekker R, Layrolle P, de Groot $\mathrm{K}$, van Blitterswijk CA (2000) Osteoinductive biomimetic calcium-phosphate coatings and their potential use as tissue-engineering scaffolds. In: Bone Engineering (Davies JE, ed), Em squared, Toronto, Canada, pp 421-431.

De Groot J (1998) Carriers that concentrate native bone morphogenetic protein in vivo. Tissue Eng 4: 337-341.

De Groot K (1973) Letter: Some considerations about bone-induction. Calcif Tissue Res 13: 335-337.

Diaz-Flores L, Gutierrez R, Lopez-Alonso A, Gonzalez R, Varela H (1992) Pericytes as a supplementary source of osteoblasts in periosteal osteogenesis. Clin Orthop Relat Res 275: 280-286.

Doherty TM, Asotra K, Fitzpatrick LA, Qiao JH, Wilkin DJ, Detrano RC, Dunstan CR, Shah PK, Rajavashisth TB (2003) Calcification in atherosclerosis: Bone biology and chronic inflammation at the arterial crossroads. Proc Natl Acad Sci U S A 100: 11201-11206.

Eid K, Zelicof S, Perona BP, Sledge CB, Glowacki J (2001) Tissue reactions to particles of bone-substitute materials in intraosseous and heterotopic sites in rats: Discrimination of osteoinduction, osteocompatibility, and inflammation. J Orthop Res 19: 962-969.

Elliot JC (1994) Structure and Chemistry of the Apatites and Other Calcium Orthophosphates. Elsevier, Amsterdam. Eniwumide JO, Yuan H, Cartmell SH, Meijer GJ, De Bruijn JD (2007) Ectopic bone formation in bone marrow stem cell seeded calcium phosphate scaffolds as compared to autograft and (cell seeded) allograft. Eur Cell Mater 14: 30-39.

Fellah BH, Josselin N, Chappard D, Weiss P, Layrolle P (2007) Inflammatory reaction in rats muscle after implantation of biphasic calcium phosphate micro particles. J Mater Sci Mater Med 18: 287-294.

Fellah BH, Gauthier O, Weiss P, Chappard D, Layrolle P (2008) Osteogenicity of biphasic calcium phosphate 
ceramics and bone autograft in a goat model. Biomaterials 29: 1177-1188.

Fellah BH, Delorme B, Sohier J, Magne D, Hardouin P, Layrolle P (2010) Macrophage and osteoblast responses to biphasic calcium phosphate microparticles. J Biomed Mater Res A 93: 1588-1595.

Friedenstein AY (1968) Induction of bone tissue by transitional epithelium. Clin Orthop Relat Res 59: 21-37. Fujibayashi S, Neo M, Kim HM, Kokubo T, Nakamura T (2004) Osteoinduction of porous bioactive titanium metal. Biomaterials 25: 443-450.

Gosain AK, Song L, Riordan P, Amarante MT, Nagy PG, Wilson CR, Toth JM, Ricci JL (2002) A 1-year study of osteoinduction in hydroxyapatite-derived biomaterials in an adult sheep model: Part I. Plast Reconstr Surg 109: 619-630.

Habibovic P, van der Valk CM, van Blitterswijk CA, De Groot K, Meijer G (2004) Influence of octacalcium phosphate coating on osteoinductive properties of biomaterials. J Mater Sci Mater Med 15: 373-380.

Habibovic P, Yuan H, van der Valk CM, Meijer G, van Blitterswijk CA, de Groot K (2005) 3D microenvironment as essential element for osteoinduction by biomaterials. Biomaterials 26: 3565-3575.

Habibovic P, Sees TM, van den Doel MA, van Blitterswijk CA, de Groot K (2006a) Osteoinduction by biomaterials - Physicochemical and structural influences. J Biomed Mater Res A 77: 747-762.

Habibovic P, Woodfield T, de Groot K, van Blitterswijk $\mathrm{C}$ (2006b) Predictive value of in vitro and in vivo assays in bone and cartilage repair - What do they really tell us about the clinical performance? Adv Exp Med Biol 585: 327-360.

Habibovic P, Yuan H, van den Doel M, Sees TM, van Blitterswijk CA, de Groot K (2006c) Relevance of osteoinductive biomaterials in critical-sized orthotopic defect. J Orthop Res 24: 867-876.

Habibovic P, Gbureck U, Doillon CJ, Bassett DC, van Blitterswijk CA, Barralet JE (2008a) Osteoconduction and osteoinduction of low-temperature $3 \underline{\mathrm{D}}$ printed bioceramic implants. Biomaterials 29: 944-953.

Habibovic P, Kruyt MC, Juhl MV, Clyens S, Martinetti R, Dolcini L, Theilgaard N, van Blitterswijk CA (2008b) Comparative in vivo study of six hydroxyapatite-based bone graft substitutes. J Orthop Res 26: 1363-1370.

Habibovic P, Juhl MV, Clyens S, Martinetti R, Dolcini L, Theilgaard N, van Blitterswijk CA (2010) Comparison of two carbonated apatite ceramics in vivo. Acta Biomater 6: 2219-2226.

Han B, Tang B, Nimni ME (2003) Quantitative and sensitive in vitro assay for osteoinductive activity of demineralized bone matrix. J Orthop Res 21: 648-654.

Hasegawa S, Neo M, Tamura J, Fujibayashi S, Takemoto M, Shikinami Y, Okazaki K, Nakamura T (2007) In vivo evaluation of a porous hydroxyapatite/poly-DLlactide composite for bone tissue engineering. J Biomed Mater Res A 81: 930-938.

Huggins C (1931) The formation of bone under the influence of epithelium of the urinary tract. Arch Surg 22: $377-408$.
Jones AC, Arns CH, Hutmacher DW, Milthorpe BK, Sheppard AP, Knackstedt MA (2009) The correlation of pore morphology, interconnectivity and physical properties of $3 \mathrm{D}$ ceramic scaffolds with bone ingrowth. Biomaterials 30: 1440-1451.

Kan L, Liu Y, McGuire TL, Berger DM, Awatramani RB, Dymecki SM, Kessler JA (2009) Dysregulation of local stem/progenitor cells as a common cellular mechanism for heterotopic ossification. Stem Cells 27: 150-156.

Kandori K, Horigami N, Kobayashi H, Yasukawa A, Isikawa T (1997) Adsorption of lysozome onto various synthetic hydroxyapatites. J Colloid Interface Sci 191: 498-502.

Kato M, Toyoda H, Namikawa T, Hoshino M, Terai H, Miyamoto S, Takaoka K (2006) Optimized use of a biodegradable polymer as a carrier material for the local delivery of recombinant human bone morphogenetic protein-2 (RHBMP-2). Biomaterials 27: 2035-2041.

Klein C, de Groot K, Chen W, Li Y, Zhang X (1994) Osseous substance formation induced in porous calcium phosphate ceramics in soft tissues. Biomaterials 15: 31-34.

Komlev VS, Mastrogiacomo M, Pereira RC, Peyrin F, Rustichelli F, Cancedda R (2010) Biodegradation of porous calcium phosphate scaffolds in an ectopic bone formation model studied by X-ray computed microtomograph. Eur Cell Mater 19: 136-146.

Kondo N, Ogose A, Tokunaga K, Umezu H, Arai K, Kudo N, Hoshino M, Inoue H, Irie H, Kuroda K, Mera H, Endo N (2006) Osteoinduction with highly purified beta-tricalcium phosphate in dog dorsal muscles and the proliferation of osteoclasts before heterotopic bone formation. Biomaterials 27: 4419-4427.

Kuboki Y, Saito T, Murata M, Takita H, Mizuno M, Inoue M, Nagai N, Poole AR (1995) Two distinctive BMPcarriers induce zonal chondrogenesis and membranous ossification, respectively; Geometrical factors of matrices for cell-differentiation. Connect Tissue Res 32: 219-226.

Kurashina K, Kurita H, Wu Q, Ohtsuka A, Kobayashi H (2002) Ectopic osteogenesis with biphasic ceramics of hydroxyapatite and tricalcium phosphate in rabbits. Biomaterials 23: 407-412.

Le Nihouannen D, Daculsi G, Saffarzadeh A, Gauthier O, Delplace S, Pilet P, Layrolle P (2005) Ectopic bone formation by microporous calcium phosphate ceramic particles in sheep muscles. Bone 36: 1086-1093.

Le Nihouannen D, Saffarzadeh A, Gauthier O, Moreau F, Pilet P, Spaethe R, Layrolle P, Daculsi G (2008) Bone tissue formation in sheep muscles induced by a biphasic calcium phosphate ceramic and fibrin glue composite. J Mater Sci Mater Med 19: 667-675.

LeGeros RZ (2008) Calcium phosphate-based osteoinductive materials. Chem Rev 108: 4742-4753.

Levander G (1934) On the formation of new bone in bone transplantation. Acta Chir Scand 74: 425-426.

Li J, Habibovic P, Yuan H, van den Doel M, Wilson CE, de Wijn JR, van Blitterswijk CA, de Groot K (2007) Biological performance in goats of a porous titanium alloybiphasic calcium phosphate composite. Biomaterials 28: 4209-4218. 
Liu Y, de Groot K, Hunziker EB (2005) BMP-2 liberated from biomimetic implant coatings induces and sustains direct ossification in an ectopic rat model. Bone 36: 745-757.

Luyten FP, Cunningham NS, Ma S, Muthukumaran N, Hammonds RG, Nevins WB, Woods WI, Reddi AH (1989) Purification and partial amino acid sequence of osteogenin, a protein initiating bone differentiation. J Biol Chem 264: 13377-13380.

Magan A, Ripamonti U (1996) Geometry of porous hydroxyapatite implants influences osteogenesis in baboons (Papio ursinus). J Craniofac Surg 7: 71-78.

Marusic A, Katavic V, Grcevic D, Lukic IK (1999) Genetic variability of new bone induction in mice. Bone 25: 25-32.

Moss ML (1958) Extraction of an osteogenic inductor factor from bone. Science 127: 755-756.

Muschler GF, Nakamoto C, Griffith LG (2004) Engineering principles of clinical cell-based tissue engineering. J Bone Joint Surg Am 86-A: 1541-1558.

Nasu T, Takemoto M, Akiyama N, Fujibayashi S, Neo M, Nakamura T (2009) EP4 agonist accelerates osteoinduction and degradation of beta-tricalcium phosphate by stimulating osteoclastogenesis. J Biomed Mater Res A 89: 601-608.

Ohgushi H, Goldberg VM, Caplan AI (1989) Heterotopic osteogenesis in porous ceramics induced by marrow cells. J Orthop Res 7: 568-578.

Ohgushi H, Dohi Y, Tamai S, Tabata S (1993) Osteogenic differentiation of marrow stromal stem cells in porous hydroxyapatite ceramics. J Biomed Mater Res 27: 1401-1407.

Ono I, Gunji H, Kaneko F, Saito T, Kuboki Y (1995) Efficacy of hydroxyapatite ceramic as a carrier for recombinant human bone morphogenetic protein. J Craniofac Surg 6: 238-244.

Pollick S, Shors EC, Holmes RE, Kraut RA (1995) Bone formation and implant degradation of coralline porous ceramics placed in bone and ectopic sites. J Oral Maxillofac Surg 53: 915-923.

Reddi AH (1981) Cell biology and biochemistry of endochondral bone development. Coll Relat Res 1: 209226.

Reddi AH (1992) Regulation of cartilage and bone differentiation by bone morphogenetic proteins. Curr Opin Cell Biol 4: 850-855.

Reddi AH (1994) Bone and cartilage differentiation. Curr Opin Genet Dev 4: 737-744.

Refai AK, Textor M, Brunette DM, Waterfield JD (2004) Effect of titanium surface topography on macrophage activation and secretion of proinflammatory cytokines and chemokines. J Biomed Mater Res A 70: 194-205.

Ripamonti U (1991) The morphogenesis of bone in replicas of porous hydroxyapatite obtained from conversion of calcium carbonate exoskeletons of coral. J Bone Joint Surg Am 73: 692-703.

Ripamonti U (1996) Osteoinduction in porous hydroxyapatite implanted in heterotopic sites of different animal models. Biomaterials 17: 31-35.
Ripamonti U (2000) Smart biomaterials with intrinsic osteoinductivity: Geometric control of bone differentiation. In: Bone Engineering (Davies JM, ed), Em squared Corporation, Toronto, Canada, pp 215-221.

Ripamonti U, van den Heever B, van Wyk J (1993) Expression of the osteogenic phenotype in porous hydroxyapatite implanted extraskeletally in baboons. Matrix 13: 491-502.

Ripamonti U, Crooks J, Kirkbride AN (1999) Sintered porous hydroxyapatites with intrinsic osteoinductive activity: Geometric induction of bone formation. South African J Sci 95: 335-343.

Ripamonti U, van den Heever B, Crooks J, Tucker MM, Sampath TK, Rueger DC, Reddi AH (2000) Longterm evaluation of bone formation by osteogenic protein 1 in the baboon and relative efficacy of bone-derived bone morphogenetic proteins delivered by irradiated xenogeneic collagenous matrices. J Bone Miner Res 15: 1798-1809.

Ripamonti U, Richter PW, Thomas ME (2007) Selfinducing shape memory geometric cues embedded within smart hydroxyapatite-based biomimetic matrices. Plast Reconstr Surg 120: 1796-1807.

Ripamonti U, Richter PW, Nilen RW, Renton L (2008) The induction of bone formation by smart biphasic hydroxyapatite tricalcium phosphate biomimetic matrices in the non-human primate Papio ursinus. J Cell Mol Med 12: 2609-2621.

Ripamonti U, Crooks J, Khoali L, Roden L (2009) The induction of bone formation by coral-derived calcium carbonate/hydroxyapatite constructs. Biomaterials 30: 1428-1439.

Ripamonti U, Klar RM, Renton LF, Ferretti C (2010) Synergistic induction of bone formation by Hop-1, HTGbeta3 and inhibition by zoledronate in macroporous coralderived hydroxyapatites. Biomaterials 31: 6400-6410.

Sasano Y, Ohtani E, Narita K, Kagayama M, Murata M, Saito T, Shigenobu K, Takita H, Mizuno M, Kuboki Y (1993) BMPs induce direct bone formation in ectopic sites independent of the endochondral ossification in vivo. Anat Rec 236: 373-380.

Sato K, Urist MR (1985) Induced regeneration of calvaria by bone morphogenetic protein (BMP) in dogs. Clin Orthop Relat Res 275: 301-311.

Selye H, Lemire Y, Bajusz E (1960) Induction of bone, cartilage and hemopoietic tissue by subcutaneously implanted tissue diaphragms. Roux' Arch Entwicklungsmech 151: 572-585.

Sorescu GP, Song H, Tressel SL, Hwang J, Dikalov S, Smith DA, Boyd NL, Platt MO, Lassegue B, Griendling KK, Jo H (2004) Bone morphogenic protein 4 produced in endothelial cells by oscillatory shear stress induces monocyte adhesion by stimulating reactive oxygen species production from a Nox1-based NADPH oxidase. Circ Res 95: 773-779.

Takemoto M, Fujibayashi S, Matsushita T, Suzuki J, Kokubo T, Nakamura T (2005) Osteoinductive ability of porous titanium implants following three types of surface treatment. In: Proc 51st Ann Meet Orthopaed Res Soc, Washington DC, poster 0992. 
Thomsen P, Gretzer C (2001) Macrophages interactions with modified material surface. Curr Opin Solid State Mater Sci 5: 163-176.

Toth J, Lynch K, Hackbarth D (1993) Ceramic-induced osteogenesis following subcutaneous implantation of calcium phosphates. Bioceramics 6: 9-13.

Uludag H, D’Augusta D, Palmer R, Timony G, Wozney J (1999) Characterization of RHBMP-2 pharmacokinetics implanted with biomaterial carriers in the rat ectopic model. J Biomed Mater Res 46: 193-202.

Urist MR (1965) Bone: Formation by autoinduction. Science 150: 893-899.

Urist MR, McLean FC (1952) Osteogenetic potency and new-bone formation by induction in transplants to the anterior chamber of the eye. J Bone Joint Surg Am 34-A: 443-476.

Urist MR, Strates BS (1971) Bone morphogenetic protein. J Dent Res 50: 1392-1406.

Urist MR, Silverman BF, Buring K, Dubuc FL, Rosenberg JM (1967) The bone induction principle. Clin Orthop 53: 243-283.

Urist MR, Huo YK, Brownell AG, Hohl WM, Buyske J, Lietze A, Tempst P, Hunkapiller M, DeLange RJ (1984) Purification of bovine bone morphogenetic protein by hydroxyapatite chromatography. Proc Natl Acad Sci USA 81: 371-375.

Vaccaro AR, Patel T, Fischgrund J, Anderson DG, Truumees E, Herkowitz HN, Phillips F, Hilibrand A, Albert TJ, Wetzel T, McCulloch JA (2004) A pilot study evaluating the safety and Efficacy of OP-1 Putty (RHBMP-7) as a replacement for iliac crest autograft in posterolateral lumbar arthrodesis for degenerative spondylolisthesis. Spine 29: 1885-1892.

Van der Stok J, Van Lieshout EM, El-Massoudi Y, Van Kralingen GH, Patka P (2011) Bone substitutes in the Netherlands - a systematic literature review. Acta Biomater 7: 739-750.

Van Eeden SP, Ripamonti U (1994) Bone differentiation in porous hydroxyapatite in baboons is regulated by the geometry of the substratum: Implications for reconstructive craniofacial surgery. Plast Reconstr Surg 93: 959-966.

Van Gaalen S, Kruyt M, Meijer G, Mistry A, Mikos A, van den Beucken J, Jansen J, de Groot K, Cancedda R, Olivo C, Yaszemski M, Dhert W (2008)Tissue engineering of bone. In: Tissue Engineering (Van Blitterswijk C, Thomsen P, Lindahl A, Hubbel J, Williams D, Cancedda R, de Bruijn J, Sohier J, eds), Academic Press, London, pp 559-610.

Vargervik K (1992) Critical sites for new bone formation. In: Bone grafts and bone substitutes (Habal MB, Reddi AH, eds), WB Saunders, Philadelphia, USA, pp 112-120.

Wallwork M, Kirkham J, Zhang J, Alastair Smith D, Brookes S, Shore R, Wood S, Ryu O, Robinson C (2001) Binding of matrix proteins to developing enamel crystals: An atomic force microscopy study. Langmuir 17: 25082513.

Wang EA, Rosen V, Cordes P, Hewick RM, Kriz MJ, Luxenberg DP, Sibley BS, Wozney JM (1988) Purification and characterization of other distinct bone-inducing factors. Proc Natl Acad Sci USA 85: 9484-9488.

Williams DF (1999) The Williams Dictionary of Biomaterials. Liverpool University Press, Liverpool, UK, pp 343.

Wilson-Hench J (1987) Osteoinduction. In: Progress in Biomedical Engineering: Definitions in Biomaterials (Williams D, ed), Elsevier, Amsterdam, pp 29.

Winter GD (1970) Heterotopic bone formation in a synthetic sponge. Proc R Soc Med 63: 1111-1115.

Winter GD, Simpson BJ (1969) Heterotopic bone formed in a synthetic sponge in the skin of young pigs. Nature 223: 88-90.

Wolfinbarger L, Jr., Zheng Y (1993) An in vitro bioassay to assess biological activity in demineralized bone. In Vitro Cell Dev Biol Anim 29A: 914-916.

Wozney JM (1998) The bone morphogenetic protein family: Multifunctional cellular regulators in the embryo and adult. Eur J Oral Sci 106 Suppl 1: 160-166.

Yamasaki H (1990) Heterotopic bone formation around porous hydroxyapatite ceramics in the subcutis of dogs. Jpan J Oral Biol 32: 190-192.

Yamasaki H, Sakai H (1992) Osteogenic Response to Porous Hydroxyapatite Ceramics under the Skin of Dogs. Biomaterials 13:308-312.

Yang Z, Yuan H, Tong W, Zou P, Chen W, Zhang X (1996) Osteogenesis in extraskeletally implanted porous calcium phosphate ceramics: Variability among different kinds of animals. Biomaterials 17: 2131-2137.

Yang ZJ, Yuan H, Zou P, Tong W, Qu S, Zhang XD (1997) Osteogenic responses to extraskeletally implanted synthetic porous calcium phosphate ceramics: An early stage histomorphological study in dogs. J Mater Sci Mater Med 8: 697-701.

Yuan H, Yang Z, Li Y, Zhang X, De Bruijn JD, De Groot K (1998) Osteoinduction by calcium phosphate biomaterials. J Mater Sci Mater Med 9: 723-726.

Yuan H, Kurashina K, de Bruijn JD, Li Y, de Groot K, Zhang X (1999) A preliminary study on osteoinduction of two kinds of calcium phosphate ceramics. Biomaterials 20: 1799-1806.

Yuan H, Li Y, de Bruijn JD, de Groot K, Zhang X (2000) Tissue responses of calcium phosphate cement: A study in dogs. Biomaterials 21: 1283-1290.

Yuan H, de Bruijn JD, Li Y, Feng Z, Yang K, de Groot K, Zhang X (2001a) Bone formation induced by calcium phosphate ceramics in soft tissue of dogs: A comparative study between Alpha-TCP and Beta-TCP. J Mater Sci Mater Med 12: 7-13.

Yuan H, de Bruijn JD, Zhang X, van Blitterswijk CA, de Groot K (2001b) Bone induction by porous glass ceramic made from bioglass (45s5). J Biomed Mater Res 58: 270276.

Yuan H, de Bruijn JD, Zhang X, van Blitterswijk CA, de Groot K (2001c) Osteoinduction by porous alumina ceramic. In: Proc Eur Conf Biomater, London, UK, pp 209.

Yuan H, de Bruijn JD, Zhang X, van Blitterswijk CA, de Groot K (2001d) Use of an osteoinductive biomaterial as a bone morphogenetic protein carrier. J Mater Sci Mater Med 12: 761-766. 
Yuan H, Yang Z, de Bruijn JD, de Groot K, Zhang X (2001e) Material-dependent bone induction by calcium phosphate ceramics: A 2.5-year study in dog. Biomaterials 22: 2617-2623.

Yuan H, Van Den Doel M, Li S, Van Blitterswijk CA, De Groot K, De Bruijn JD (2002) A comparison of the osteoinductive potential of two calcium phosphate ceramics implanted intramuscularly in goats. J Mater Sci Mater Med 13: 1271-1275.

Yuan H, van Blitterswijk CA, de Groot K, de Bruijn JD (2006a) A comparison of bone Formation in biphasic calcium phosphate (BCP) and hydroxyapatite (HA) implanted in muscle and bone of dogs at different time periods. J Biomed Mater Res A 78: 139-147.

Yuan H, van Blitterswijk CA, de Groot K, de Bruijn JD (2006b) Cross-species comparison of ectopic bone formation in biphasic calcium phosphate (BCP) and hydroxyapatite (HA) scaffolds. Tissue Eng 12: 1607-1615.

Yuan H, Fernandes H, Habibovic P, de Boer J, Barradas AM, de Ruiter A, Walsh WR, van Blitterswijk CA, de Bruijn JD (2010) Osteoinductive ceramics as a synthetic alternative to autologous bone grafting. Proc Natl Acad Sci U S A 107: 13614-13619.

Yuan H, Fernandes H, Habibovic P, de Boer J, Barradas AMC, De Ruiter A, Walsh WR, van Blitterswijk CA, de Bruijn JD (2011) "Smart" biomaterials and osteoinductivity. Nat Rev Rheumatol 7: 8-9.

Zaffe D (2005) Some considerations on biomaterials and bone. Micron 36: 583-592.

Zhang M, Powers RM, Jr., Wolfinbarger L, Jr. (1997) A quantitative assessment of osteoinductivity of human demineralized bone matrix. J Periodontol 68: 1076-1084.

Zhang X (1991)A study of porous block HA ceramics and its osteogenesis. In: Bioceramics and the Human Body (Ravaglioli A, Krajewski A, eds), Elsevier Science, Amsterdam, The Netherlands, pp 692-703.

Zheng B, Cao B, Crisan M, Sun B, Li G, Logar A, Yap S, Pollett JB, Drowley L, Cassino T, Gharaibeh B, Deasy BM, Huard J, Peault B (2007) Prospective identification of myogenic endothelial cells in human skeletal muscle. Nat Biotechnol 25: 1025-1034.

Zhou H, Wu T, Dong X, Wang Q, Shen J (2007) Adsorption mechanism of BMP-7 on hydroxyapatite (001) surfaces. Biochem Biophys Res Commun 361: 91-96.

\section{Discussion with Reviewer}

Reviewer II: Would osteoconduction cause more healing in an orthotopic site compared to the additional weak osteoinduction observed in the heterotopic site? The phenomenon of bone induction by calcium phosphates in heterotopic sites is so weak (taking months for a small amount of bone) that it might be esoteric and not clinically relevant. What is the clinical implication of these data?

Authors: These are indeed highly relevant questions, and the main rationale behind the effort to develop osteoinductive biomaterials. First regarding relevance of osteoinduction in orthotopic implantation sites, it should be noted that we have performed a number of experiments in which ceramics with varying osteoinductive potential were compared in clinically relevant orthotopic defects. For example, in the study by Habibovic et al. (2006c, text reference) two biphasic calcium phosphate ceramics were implanted both heterotopically in paraspinal muscles, and orthotopically in a critical-sized iliac wing defect in goats. The ceramic that showed bone formation heterotopically also demonstrated significantly more bone orthotopically than the non-osteoinductive ceramic. Similar results were obtained in another study (Habibovic et al., 2010, text reference). Finally, in a recent study by our group, osteoinductive TCP ceramic showed at least equal amount of bone formation in a critical-sized iliac wing defect in sheep as rh-BMP-2 on a collagen carrier and autologous bone (Yuan et al., 2010, text reference). These data clearly show the benefit of osteoinductive materials orthotopically. There are some indications that this benefit can (at least partially) be attributed to osteoinduction that occurs orthotopically (Habibovic et al., 2006c, text reference), but we will need to define the exact biological mechanism behind osteoinduction to give a conclusive evidence for this. Regarding clinical implications, we realise that it is difficult, if not impossible to extrapolate data obtained in animal models to the clinical situation, certainly considering large inter-species differences as described in this manuscript. Therefore, only clinical trials can provide evidence for clinical relevance of osteoinductive biomaterials. 